OPEN ACCESS

Edited by:

John Stix,

McGill University, Canada

Reviewed by:

Timothy Druitt,

Blaise Pascal University, France Craig A. Chesner,

Eastern Illinois University, USA

*Correspondence:

Shanaka L. de Silva

College of Earth, Ocean, and Atmospheric Science, Oregon State

University, 104 CEAOS Admin Building, Corvallis, OR 97331, USA

desilvas@geo.oregonstate.edu

Specialty section:

This article was submitted to

Volcanology,

a section of the journal

Frontiers in Earth Science

Received: 16 January 2015 Accepted: 19 May 2015

Published: 09 June 2015

Citation:

de Silva SL, Mucek AE, Gregg PM and Pratomo I (2015) Resurgent

Toba-field, chronologic, and model

constraints on time scales and mechanisms of resurgence at large calderas. Front. Earth Sci. 3:25. doi: 10.3389/feart.2015.00025

\section{Resurgent Toba-field, chronologic, and model constraints on time scales and mechanisms of resurgence at large calderas}

\author{
Shanaka L. de Silva ${ }^{1,2 *}$, Adonara E. Mucek ${ }^{1,2}$, Patricia M. Gregg ${ }^{1,3}$ and Indyo Pratomo ${ }^{4}$ \\ ${ }^{1}$ College of Earth, Ocean, and Atmospheric Science, Oregon State University, Corvallis, OR, USA, ${ }^{2}$ Earth Observatory of \\ Singapore, Nanyang Technological University, Singapore, Singapore, ${ }^{3}$ Department of Geology, University of Illinois - \\ Urbana-Champaign, Champaign, IL, USA, ${ }^{4}$ Geological Agency of Indonesia, Geological Museum, Bandung, Indonesia
}

\section{Highlights}

- New data reveal for the first time a history of the last $\sim 33.7 \mathrm{ky}$ of uplift of Samosir.

- Minimum uplift rates were high $(4.9 \mathrm{~cm} /$ year) for the first $11.2 \mathrm{ky}$ but diminished after that to $<1 \mathrm{~cm} /$ year for the last $22.5 \mathrm{ky}$.

- Numerical modeling suggests that rebound of remnant magma augmented by deep recharge appears to be the most likely driver for uplift.

- Detumescence makes a negligible contribution to resurgent uplift.

- The volume of the resurgent dome is isostatically compensated by magma

- Average rates of uplift at Toba are much lower than currently restless calderas indicating a distinction between resurgence and "restlessness".

New data reveal details of the post-caldera history at the Earth's youngest resurgent supervolcano, Toba caldera in Sumatra. Resurgence after the caldera-forming $\sim 74 \mathrm{ka}$ Youngest Toba Tuff eruption uplifted the caldera floor as a resurgent dome, Samosir Island, capped with $100 \mathrm{~m}$ of lake sediments. ${ }^{14} \mathrm{C}$ age data from the uppermost datable sediments reveal that Samosir Island was submerged beneath lake level ( $900 \mathrm{~m}$ a.s.l) at $33 \mathrm{ka}$. Since then, Samosir experienced $700 \mathrm{~m}$ of uplift as a tilted block dipping to the west. ${ }^{14} \mathrm{C}$ ages and elevations of sediment along a transect of Samosir reveal that minimum uplift rates were $\sim 4.9 \mathrm{~cm} /$ year from $\sim 33.7$ to $22.5 \mathrm{ka}$, but diminished to $\sim 0.7 \mathrm{~cm} /$ year after $22.5 \mathrm{ka}$. Thermo-mechanical models informed by these rates reveal that detumescence does not produce the uplift nor the uplift rates estimated for Samosir. However, models calculating the effect of volume change of the magma reservoir within a temperature-dependent viscoelastic host rock reveal that a single pulse of $\sim 475 \mathrm{~km}^{3}$ of magma produces a better fit to the uplift data than a constant flux. The cause of resurgent uplift of the caldera floor is rebound of remnant magma as the system re-established magmastatic and isostatic equilibrium after the caldera collapse. Previous assertions that the caldera floor was apparently at $400 \mathrm{~m}$ a.s.I or lower requires that uplift must have initiated between sometime between 33.7 and $74 \mathrm{ka}$ at a minimum average uplift rate of $\sim 1.1 \mathrm{~cm} /$ year. The change in uplift rate from pre-33.7 ka to immediately post-33.7 ka suggests a role for deep recharge augmenting rebound. Average minimum rates of 
resurgent uplift at Toba are at least an order of magnitude slower than net rates of "restlessness" at currently active calderas. This connotes a distinction between resurgence and "restlessness" controlled by different processes, scales of process, and controlling variables.

Keywords: Carbon-14 dating, lake sediments, Toba caldera, resurgence, numerical modeling, magmatic intrusion, magmastatic equilibrium, remnant magma

\section{Introduction}

Large silicic calderas with diameters of several tens of kilometers such as Yellowstone, Toba, Valles, and Long Valley Caldera, are loci of the most explosive eruptions on Earth (Miller and Wark, 2008; Mastin et al., 2014). Some of the largest eruptions result in the evacuation of up to $3000 \mathrm{~km}^{3}$ of magma $\left(\sim 7 \times 10^{15} \mathrm{~kg}\right.$ or Magnitude 8.8 ) roughly equivalent to $\sim 8000 \mathrm{~km}^{3}$ of tephra deposits (Self and Blake, 2008). These have the potential to impact the earth on both local and global scales, devastating regions, and affecting the global climate (Oppenheimer, 2002; Williams et al., 2009). The resulting calderas are thought to form when the roof of the magma chamber collapses into the magma chamber. The collapse may happen late in the eruption sequence either due to loss of support or underpressure caused by evacuation of the magma (e.g., Roche and Druitt, 2001) or early in the eruption due to failure of a weak and extended roof into a perched and primed magma reservoir (Gregg et al., 2012). After the "climactic" eruption and formation of the caldera, a period of recovery or "resurgence," the afterparty to the big dance so to speak, is manifested as volcanic activity in the form of effusive lava eruptions and/or structural uplift of the caldera floor and intracaldera ignimbrite in the form of block uplift or a dome (Smith and Bailey, 1968; Acocella, 2007). At large calderas, magmatic activity and structural uplift are often inter-related and contemporaneous. While resurgence is often seen as the waning stage of a caldera cycle, it is also one of the most dynamic phases as evinced by the "restless" nature of currently active calderas. Structural uplift promotes faulting and permeability that may result in further eruptions or the development of hydrothermal and geothermal systems through percolation of meteoric fluids downwards, enhancing the conditions for ore formation (Smith and Bailey, 1968; Lipman, 1984; Kennedy et al., 2012). Many calderas host large lakes, and these may pose considerable hazard if rapidly drained (e.g., Goff et al., 1992) and may involve flooding and tsunami hazard if rapid uplift triggers landslides and collapse (Chen et al., 1995; Tibaldi and Vezzoli, 2004). Despite the recognition of the restless and transitional nature of resurgence, the mechanisms responsible remain poorly understood. The significant scientific effort that has been directed at understanding caldera formation and the build up to large caldera forming eruptions is in stark contrast to the relatively little effort that has been invested to understand the process of resurgence. This is cause for concern because all large active calderas on Earth are in resurgence (Newhall and Dzurisin, 1988). This imbalance needs to be addressed.

One of the main challenges to understanding resurgence is to unravel the spatiotemporal signals and integrate these with structural signals. In particular, estimates of rates of resurgent deformation are highly variable. For instance, young active systems record very high, variable rates. Raised wave-cut terraces at Iwo-Jima caldera in the Izu- Bonin volcanic arc, located about $1150 \mathrm{~km}$ south of Tokyo in the Pacific Ocean, indicate uplift rates averaging $15-20 \mathrm{~cm} /$ year during the last $500-700$ years (Kaizuka et al., 1989; Fisher et al., 1997). A comparable rate of $15.6 \mathrm{~cm} /$ year from 1002 to 1992 A.D. was reported for the Yenkahe Resurgent Block, Tanna, Vanuatu using emerged reef terraces (Chen et al., 1995). The Campi Flegrei caldera, located near Naples, Italy, is a complex resurgent caldera that has undergone two recent episodes of major uplift (1969-1972 and 1982-1984). During these episodes, average uplift rates of approximately $1.4 \mathrm{~mm} /$ day (51 cm/year) were recorded (Orsi et al., 1999). The episodicity of resurgence in this caldera is manifested by subsidence that occurred after both uplift episodes. At the actively deforming $20 \mathrm{~km}$ diameter Laguna del Maule caldera in Chile, Feigl et al. (2014) report exceptionally rapid deformation of $\sim 28 \mathrm{~cm} /$ year (vertical velocity) during the five years from 2007 to 2012. At very large calderas like Yellowstone, active deformation rates as high as $2.7 \mathrm{~cm} /$ year have been reported based on precise leveling measurements (Pelton and Smith, 1979; Jackson et al., 1984), but such uplift is spatially and temporally variable and limited, and subsidence has also been recorded (Smith and Braile, 1994; Dzurisin et al., 1999). Maximum resurgence rates reported for Long Valley caldera are as high as $5 \mathrm{~cm} /$ year (Savage and Clark, 1982) and the most recent seismic unrest (1978-1999) resulted in uplift of $80 \mathrm{~cm}$, at an average rate of $3.8 \mathrm{~cm} /$ year (Sorey et al., 2003). "Restlessness" at Yellowstone and Long Valley is occurring 600-700 ka after the last major eruptions at these calderas. We note, however, that the "restlessness" is on a very limited spatial scale and is not recorded on the scale of the entire caldera.

On the other hand, fossil resurgent uplifts of kilometer high domes and blocks of intracaldera ignimbrite with areal footprints of hundreds of $\mathrm{km}^{2}$ characterize the largest resurgent calderas such as Toba (van Bemmelen, 1939), Valles (Smith and Bailey, 1968), Creede and La Garita (Lipman, 1975), La Pacana (Lindsay et al., 2001) and Cerro Galan (Folkes et al., 2011). Available time constraints suggest uplift occurred over durations of $10^{4}-10^{5}$ years (Smith and Bailey, 1968; Marsh, 1984) at average rates much lower than those for the restless calderas mentioned above. For instance, for the Upper Bandelier Tuff (UBT) caldera cycle at the Valles Caldera, New Mexico, Phillips et al. (2007) found that post collapse volcanism commenced shortly (unresolvable time lag) after caldera collapse and resurgent uplift occurred over a duration of $27 \pm 27 \mathrm{ka}$, or $<54 \mathrm{ka}$ calculated from the difference in the ${ }^{40} \mathrm{Ar} /{ }^{39} \mathrm{Ar}$ ages of sanidine from the UBT $1.256 \pm 0.010$ $\mathrm{Ma}$ and the Cerro del Medio dome 1.229 $\pm 0.017 \mathrm{Ma}$ (the oldest 
post collapse dome). An average rate of uplift was calculated at $\sim 1.9 \mathrm{~cm}$ /year, although an arbitrary duration of 1000 years could be used to suggest rates of $100 \mathrm{~cm} /$ year (Phillips et al., 2007 end of their page 10). Given the uncertainties in the ArAr age data used at Valles, it would be reasonable to suggest that rates anywhere between the two values are permissible. At Campi Flegrei, longer term rates for restless calderas are much lower than historic or recent rates. Sacchi et al. (2014) report net uplift rates of $0.9-1.2 \mathrm{~cm} /$ year during the period 15.0-6.6 ka BP.

It might be possible to reconcile the different time scales by suggesting that the transient "restless" rates are offset by periods of inactivity or subsidence to produce lower long-term rates. However, we note that over 400 years a net uplift rate of $25 \mathrm{~cm}$ /year at Satsuma-Iwo Jima produced the $100 \mathrm{~m}$ of uplift (C. Newhall pers. comm). If $25 \mathrm{~cm} /$ year is characteristic of long term uplift rates that produce the fossil structural uplifts, then a $1 \mathrm{~km}$ uplift could be produced in a period as short as 4000 years. However, such rapid time scales are inconsistent with the time scales of plausible mechanisms for resurgence at large calderas where Marsh (1984) has calculated time scales of $10^{4}$ and $10^{5}$ years-orders of magnitude slower. Clearly there is significant disconnect in current understanding of structural resurgence at calderas. Kennedy et al. (2012) propose a relationship between the uplift rate and the amount of uplift seen, where a higher uplift rate over a shorter timescale produces less uplift than a lower uplift rate over a longer timescale. They distinguish a set of shallow mechanisms such as fluid (hydrothermal) activity, small intrusions and ring dykes that produce short term, episodic uplift from larger-scale deeper mechanisms, such as magmatic readjustments and intrusions that would result in slower uplift rates that act on a much longer-term. Testing this dichotomy requires finding a system that not only faithfully preserves the geological record of resurgence, but is also youthful enough that the time scale can be resolved with available chronometers. Ancient calderas such as those in the Central Andes offer spectacular preservation of resurgent domes and associated extrusions, but the time scale of resurgence is subsumed in the precision of age data as at the Valles Caldera, New Mexico. One of the few systems that potentially meets the requirements is Toba Caldera, Sumatra. Here we present new results of our preliminary efforts to unravel the resurgent uplift history of the $\sim 74$ ka Toba caldera, Sumatra (Figure 1).

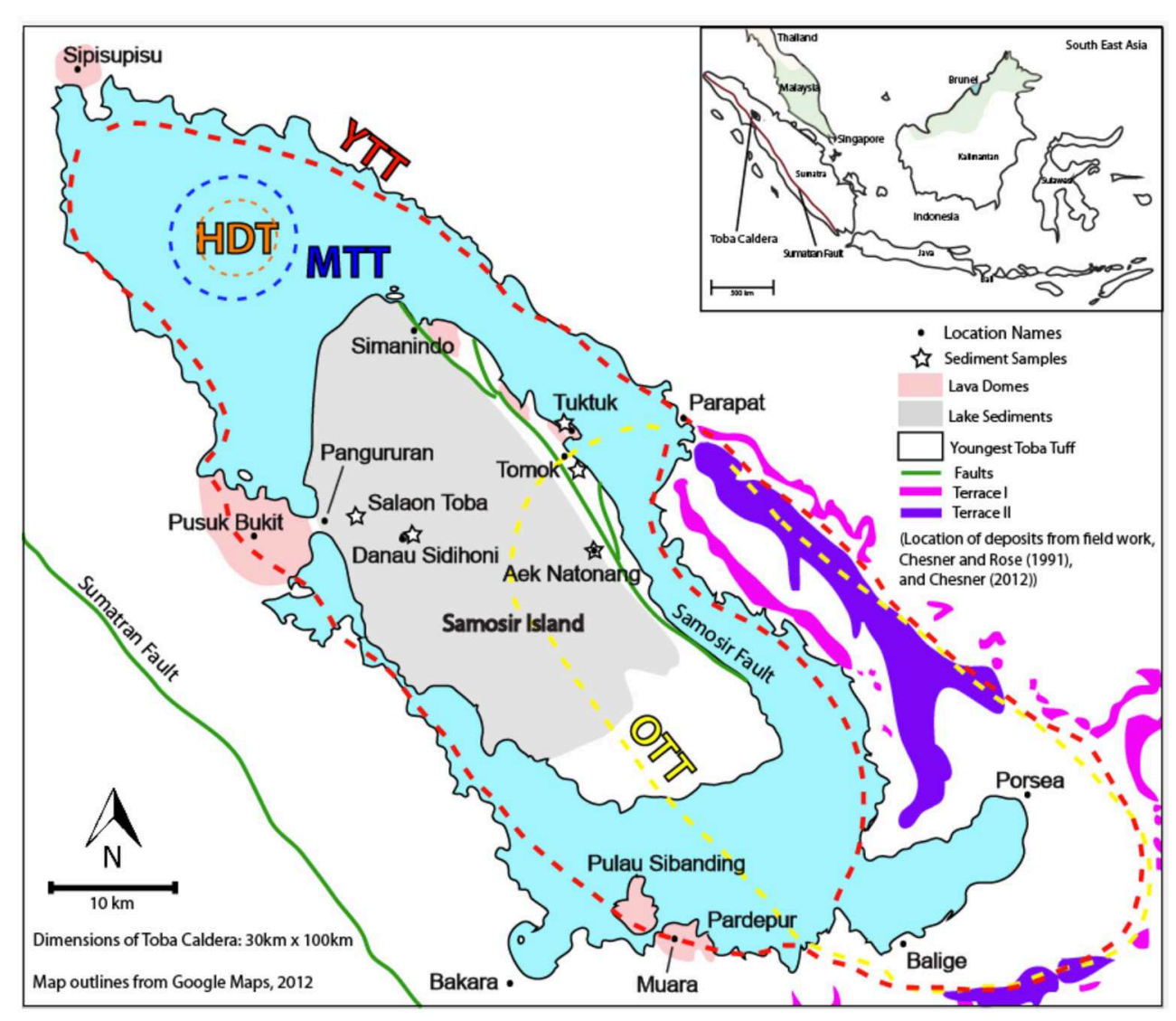

FIGURE 1 | Location map and main features of Toba Caldera, Sumatra that are discussed the text. Approximate caldera outlines for the various eruptions of Toba are taken from Chesner (2012). Location of ${ }^{14} \mathrm{C}$ samples in Table 1 and referred to in the text are shown. Inset shows the location of
Toba in South East Asia. HDT, Harrangaol Dacite Tuff, erupted 1.2 Ma; OTT, Oldest Toba Tuff, erupted $\sim 0.84 \mathrm{Ma}$; MTT, Middle Toba Tuff, erupted $\sim 0.5$ Ma; YTT, Youngest Toba Tuff, erupted $\sim 74$ ka (Chesner, 2012). Lake terraces of Verstappen (1973) are shown in magenta and purple. 


\section{Toba, Sumatra}

Toba Caldera, in Sumatra, Indonesia, is one of the first places "resurgence" was recognized and documented (van Bemmelen, 1929,1939 ). The last $\sim 74$ ka eruption has captured the attention of scientists for several reasons. The large magnitude 8.8 eruption coincides in time with the transition from marine isotope stage 5 to stage 4 , raising questions about its effect on the global climate and regional effects on hominids, flora, and fauna (Williams et al., 2009; Haslam and Petraglia, 2010; Chesner, 2012; Jones, 2012; Oppenheimer, 2012; Williams, 2012). While the stratigraphy, chronology, and distribution of the eruptive deposits are well established and the development of the caldera and magmatic system is generally well investigated (van Bemmelen, 1929, 1939; Aldiss and Ghazali, 1984; Chesner and Rose, 1991; Chesner, 1998), there has been little emphasis on the resurgence stage of Toba Caldera, despite the resurgence history being well recorded by the deposition of lake sediments on the resurgent dome and in the post-caldera lava activity (Chesner, 2012).

A significant volume of work has focused on the development of the Toba system dating back to van Bemmelen (1929, 1939). The review by Chesner (2012) provides the most up-todate summary of the state of knowledge. Although originally thought to have been the result of a single catastrophic eruption, the Toba caldera is now known to be a nested caldera complex consisting of overlapping, broadly co-located, caldera collapses. Its relationship to regional tectonics, the regional uplift of the Batak Tumor and the Samosir Fault led van Bemmelen (1939) to propose that it was a volcano-tectonic depression.

The following is a summary of its geologic history taken from the works cited above. Major eruptive activity initiated $\sim 1.2$ Ma with the Haranggaol Dacite Tuff (HDT), followed by the catastrophic eruption of the $\sim 500-2300 \mathrm{~km}^{3}$ Oldest Toba Tuff $(\mathrm{OTT})$ at $\sim 840 \mathrm{ka}$ that resulted in collapse of the Porsea caldera (Knight et al., 1986; Chesner, 2012). A smaller eruption focused in the north produced the $60 \mathrm{~km}^{3}$ Middle Toba Tuff (MTT) at $\sim 501 \mathrm{ka}$ (Chesner et al., 1991), while most of the resurgent caldera we see today was produced during the catastrophic eruption of the $2800 \mathrm{~km}^{3}$ Youngest Toba Tuff (YTT) most recently dated at $73.9 \pm 0.6 \mathrm{ka}$ by Storey et al. (2012) and at 75.0 \pm $0.9 \mathrm{ka}$ by Mark et al. (2013). This eruption produced the most recent caldera described as a $2 \mathrm{~km}$ deep steep-walled collapse with a flat floor of thick welded YTT at a maximum elevation of $400 \mathrm{~m}$ a.s.l (above sea level), but maybe as low as sea level. The caldera is thought to have filled rapidly to form a lake in a time period of $<1500$ years. After some rapid downcutting at the outlet, it is now at $\sim 906 \mathrm{~m}$ above sea level (Chesner, 2012). Fluvial drainages and mass wasting introduced sediments into the lake soon after. Sedimentation close to the walls would have been coarse, with finer sedimentation occurring in the interior of the lake. Resurgent uplift of Samosir, the regional westward tilt, en echelon faulted eastern margin, absence of lake terraces, and thick accumulation of diatomaceous lake sediments (Samosir Formation of Aldiss and Ghazali, 1984) were recognized by van Bemmelen (1939). Approximately $1100 \mathrm{~m}$ of uplift of the caldera

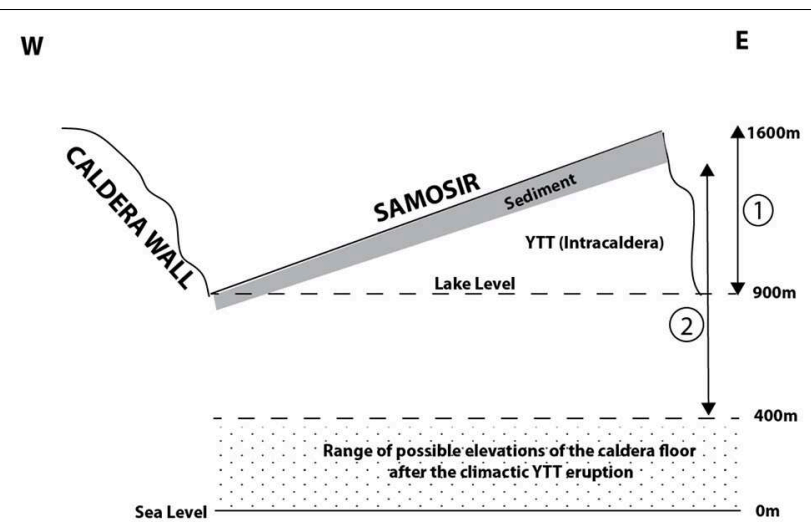

FIGURE 2 | Schematic cross section of Toba Caldera illustrating critical measurements and features for interpreting the resurgent uplift of Samosir. (1) is the $700 \mathrm{~m}$ of uplift estimated since $~ 33 \mathrm{ka}$ when the uppermost sediment must have been at lake level. (2) is the maximum uplift of $1100 \mathrm{~m}$ if the caldera floor was at $400 \mathrm{~m}$ a.s.l. after the YTT eruption $\sim 74 \mathrm{ka}$ (based on Chesner, 2012). We note that the caldera floor could have been as low as sea level (Chesner, 2012). Vertical is to scale, horizontal is not.

floor has been estimated (Figure 2, Chesner, 2012). The eastern compliment to Samosir, Uluan, also resurged but considerably less than Samosir, possibly only 250-300 m (Chesner and Rose, 1991). On northeastern Samosir Island, several clusters of lava dome emplacement have been identified at or near lake level, having erupted along the Samosir faults (Figure 1). These are collectively known as the Samosir Lava Domes and include the Tuk Tuk domes that define the eponymous peninsula. The youngest post-YTT eruptions are thought to be those between Samosir and the western caldera wall extending down toward the town of Muara. These include the Pusuk Bukit composite volcano and the Pardepur domes. Aligned with these are several areas of recent uplift and significant hydrothermal activity. Sipisupisu or Tandukbenua volcano on the northwestern tip of the caldera and its "partner" Singgalang are probably among the most recent in the Toba region. The active arc composite cones of Sinabung (erupting at the time of writing since 2013) and Sibayak approximately $20 \mathrm{~km}$ northwest of Toba are not considered part of the Toba system.

Despite this significant body of work, the understanding of resurgence at Toba is limited. In particular, a coherent age framework is not available. ${ }^{40} \mathrm{Ar} /{ }^{39} \mathrm{Ar}$ age determinations of the post-YTT Samosir Lava Domes are reported to be 75$77 \mathrm{ka}$ (Chesner, 2012). Despite the concordance in ages with the YTT, Chesner (2012) makes it clear that any relation to the YTT eruption is unlikely as "their location and thin to absent sedimentary veneer is inconsistent with this interpretation". A single ${ }^{14} \mathrm{C}$ date of $33,090 \pm 570$ years ago, obtained from near the top of the lake sediment stratigraphy shows that the resurgent dome was under water at this time (Chesner, 2012). Based on this one age, Chesner (2012) calculates a minimum $1.8 \mathrm{~cm} /$ year rate of uplift. Chesner and Rose (1991) proposed that either magmatic pressure or regional detumescence caused the postYTT resurgent uplift. 


\section{Approach and Methods}

We focused on the most recent sediments on Samosir, the Samosir Formation of Aldiss and Ghazali (1984), as they provide the most reliable index of the most recent submergence of Samosir and thus an elevation datum (lake level) that is spatially and temporally consistent. The older sediments near the base of the sequence are beyond the radiocarbon technique that we have employed. Moreover, an elevation datum for older sediments is not available as we do not know at what elevation they formed nor when they became subaerial. Sediment cover is best developed on the northern half of the island, while the more dissected southern slopes of the island appear to have no sediment cover. Access is impossible for most of the southern area, but where we could access we found tuff at the surface, not sediments. The tuff is pervasively altered to clay where we could access it but presume it is YTT based on inferred continuity and previous work.

Our stratigraphic logging throughout the northern sedimentary sequence reveals that there are two main types of sediment (Figure 3). Extensive rhythmically bedded and laminated sands to muds are found in the upper elevations with occasional distinct ash horizons. Fluvial sands and coarse debris flows both conformable and cross cutting (channelized) are found toward the top. Layers containing wood and plant debris attest to periods of inundation or avalanche of extensively vegetated slopes. The second type of sediment is tuffaceous, ashy sediment with distinct diatomaceous horizons in the lower western reaches of Samosir. This sequence of lake sediments above the YTT on Samosir Island is up to $100 \mathrm{~m}$ thick in places and contains a rich record of the resurgent history of Samosir that includes distal and proximal input of material from the caldera walls.

Seven samples of wood and organic-rich sediment were analyzed by accelerator mass spectrometry (AMS) at Beta Analytic (Table 1 and Table S1 in Supplementary Data). For our wood samples, Beta used an acid-base-acid (ABA) wash pretreatment at $\sim 70^{\circ} \mathrm{C}$ with $1 \mathrm{~N} \mathrm{HCl}$ and $1 \mathrm{~N} \mathrm{NaOH}$, with the base washes repeated until the extract humic acid was fully removed. For organic sediment an acid wash was used. All results were corrected using the on-line $\delta^{13} \mathrm{C}$ AMS values of the respective graphite aliquots measured, following instrumental analysis described in Santos et al. (2007). The blank correction was obtained from ${ }^{14} \mathrm{C}$ analysis of the two wood samples LT003 and LT004, subjected to the standard ABA pretreatment mentioned above. Resulting ages are reported both as conventional ${ }^{14} \mathrm{C}$ ages (year BP) as well as $95.4 \%$ (2-sigma) probability calendar age ranges (cal year $\mathrm{BP}$ ) calibrated by $\mathrm{OxCal}$
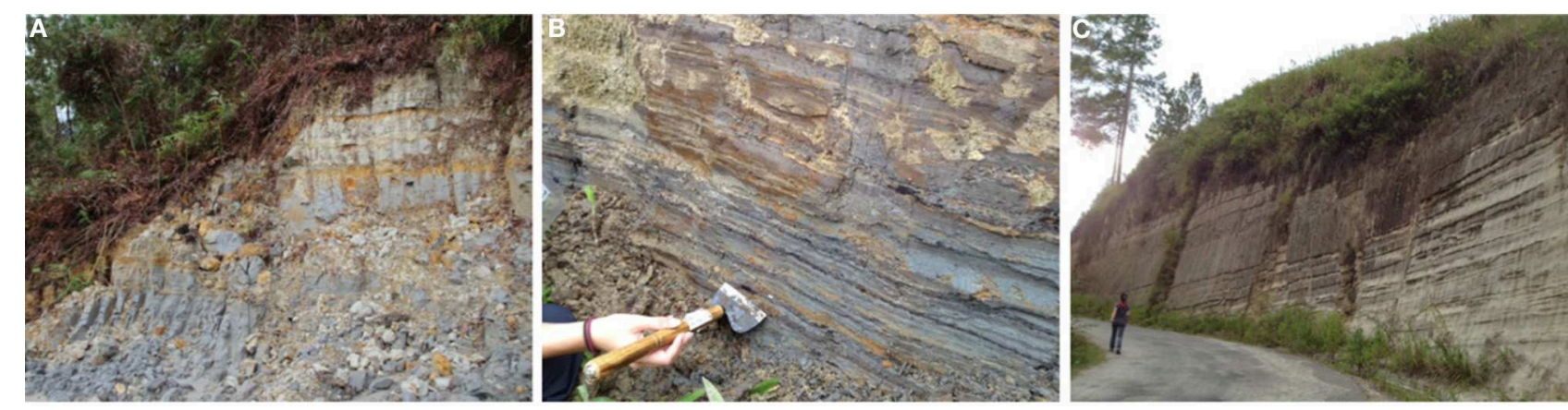

FIGURE 3 | The sequence of lake sediments above the YTT on Samosir Island is up to $100 \mathrm{~m}$ thick in places and contains a rich record of the resurgent history of Samosir that includes distal and proximal input of material from the caldera walls. (A) $8 \mathrm{~m}$ of extensive rhythmically bedded and laminated sands to muds ( $33 \mathrm{ka}$ in uppermost part) in the upper elevations of Samosir near Aek Natonang with occasional distinct ash horizons. Fluvial sands and coarse debris flows both conformable with and cross cutting (channelized) are found toward the top. (B) Wood containing layers at Tomok attest to periods of inundation or avalanche of the eastern fault scarp. These have yielded ages of $\sim 22 \mathrm{ka}$. (C) Tuffaceous, ashy sediment with distinct diatomaceous horizons in the lower western reaches of Samosir. Faulting (stepping down to the east (right) is prominent here (Near Danau Sidihoni).

TABLE $1 \mid{ }^{14} \mathrm{C}$ analytical results.

\begin{tabular}{|c|c|c|c|c|c|c|}
\hline Sample & Lab No. & Material: Pretreatment & $\begin{array}{l}{ }^{14} \mathrm{C} \mathrm{Age} \pm 1 \sigma \\
\text { year BP }\end{array}$ & $\begin{array}{c}{ }^{13} \mathbf{C} /{ }^{12} \mathbf{C} \\
\% 0\end{array}$ & $\begin{array}{l}\text { Conventional Age } \\
\quad \pm 1 \sigma \text { year BP }\end{array}$ & $\begin{array}{c}\text { Calibrated age range ( } 95.4 \% \text { probability) } \\
\text { Cal years BP }\end{array}$ \\
\hline TOBA 1 & 347762 & Organic sediment: acid washes & $28160 \pm 150$ & -21.4 & $28220 \pm 150$ & 32980-31940 \\
\hline TOBA 2 & 347763 & Organic sediment: acid washes & $8220 \pm 40$ & -24.9 & $8220 \pm 40$ & 9300-9030 \\
\hline TOBA 3 & 347764 & Wood: acid/alkali/acid & $22630 \pm 100$ & -28.9 & $22570 \pm 100$ & 27710-26870 \\
\hline TOBA 4 & 347765 & Wood: acid/alkali/acid & $22430 \pm 100$ & -26.2 & $22410 \pm 100$ & $27580-26740$ \\
\hline TOBA 5 & 351723 & Organic sediment: acid washes & $33720 \pm 240$ & -24.5 & $33730 \pm 240$ & 38960-38370 \\
\hline TOBA 6 & 351724 & Organic sediment: acid washes & $28560 \pm 150$ & -22.3 & $28660 \pm 150$ & 33560-33180 \\
\hline TOBA 7 & 351725 & Organic sediment: acid washes & $21250 \pm 90$ & -25.9 & $21240 \pm 90$ & 25660-25060 \\
\hline
\end{tabular}


4.1 (Ramsey, 2009) using the IntCal09 calibration curve (Reimers et al., 2009).

\section{Lake Level Datum Used In this Study}

Our approach requires a fiduciary lake level and we adopt the current lake level, $\sim 906 \mathrm{~m}$ above sea level, as the long term lake level since it filled up after the $\sim 74 \mathrm{ka}$ eruption. This lake level is maintained by a hydroelectric dam at the outlet of the Asahan valley (near Porsea). The dam is built into bedrock at the level of the outlet; there is no record of the lake being drained substantially to achieve a lower lake level at the time the dam was built. Hence, we assume that the lake was at that level naturally. This deviates from Chesner (2012) who estimated the lake level to be $\sim 1000 \mathrm{~m}$ at $33 \mathrm{ka}$.

Previous high stands of lakes in the Toba basin are indeed recorded (Verstappen, 1973). Two sets of lake terraces occur in the kidney-shaped remnant of the Porsea caldera that makes up the southeastern and southern part of Toba basin extending from Prapat to Balige. These have elevations of $1160 \mathrm{~m}$ (Terrace I) and $1050 \mathrm{~m}$ (Terrace II) and are found etched into the OTT and YTT between Prapat and Porsea (Figure 1). These can be traced along the eastern caldera wall from Prapat to Porsea, where they are uplifted and warped with elevations up to $1400 \mathrm{~m}$ (Verstappen, 1973). Chesner and Rose (1991) suggest that this is due to resurgent uplift that affected Uluan and the eastern topographic margin. Rotation of Uluan about an axis to the west is proposed to account for the offset elevation of Terrace I on either side of the Prapat Graben. Both of these lake terraces are recorded near the outlet of the Asahan valley, which has always drained Lake Toba (Verstappen, 1973). We note that there are also traces of terraces at 1130, 1100, 1010, 1000 950, 930, and $913 \mathrm{~m}$ between Balige and Porsea (Verstappen, 1973). While there are no ages on these terraces, they are presumed to be post-YTT because the main Terraces I and II are incised into the YTT. The entire record of lake terraces could therefore speak to the lake history of the entire Toba caldera. However, we are struck by the fact that this record is only found in the remnant Porsea caldera.

There is no evidence of these high lake levels in the main Toba lake basin, nor in the Samosir lake sediment or intra-caldera YTT (noted by all previous workers here). If the present lake had been at 1160 or $1050 \mathrm{~m}$ or at any of the other terrace elevations, we would expect this to be recorded as terraces around the YTT caldera. The argument that such terraces wouldn't develop in indurated rocks (Verstappen, 1973) is counter to the observations of terraces in the OTT in the eastern topographic wall, the Asahan valley, and the basement volcanics south of the Balige/Muara area. Moreover, we would expect to see stranded deltas from the rivers that drain off Samosir and the surrounding highlands. We have found none.

Thus, the record of higher lake levels is only found in the remnant of the Porsea caldera. When this fact is combined with the quite distinct uplift history of Uluan and the obvious difference in the topography and bathymetry of the remnant Porsea caldera to the deeper main basin in which Samosir is found, it is possible that a separate kidney-shaped basin from Prapat to the Balige area existed after the YTT eruption. This
"Porsea basin" could have had a different lake history to the main basin, and this is what is recorded in the two main terraces and the subsequent terraces. For these reasons we proceed with a lake level datum of $\sim 900 \mathrm{~m}$ (rounded down from $906 \mathrm{~m}$ ) until a better estimate is available. A summary of the key elevations we use in this study are shown in Figure 2.

\section{Uplift of Samosir}

Samosir island is a very broad shallow, tilted half-dome. Given the dominance of the surface area to the height of the structure we treat it simply as a shallow tilted block like those at other calderas such as Pantelleria and Ischia in the Mediterranean (e.g., Orsi et al., 1991), although those are much smaller. The westward tilted surface is at lake level on its western side at Pangururan, and rises up to as high as $700 \mathrm{~m}$ above lake level on the highest elevation on top of the eastern scarp near Aek Natonang (Sample site Toba 5). ${ }^{14} \mathrm{C}$ age determinations from three samples along a transect from lake level on the west across the upper surface of Samosir (Figure 4; Table 1) yield ages of 28,220 \pm 150 years (Toba $1 ; 1035 \mathrm{~m}$ elevation), 28,660 \pm 150 years (Toba 6; $1302 \mathrm{~m}$ ), and $33,730 \pm 240$ years (Toba 5; $1600 \mathrm{~m}$ ). Along with the single age of 33,090 \pm 570 years presented by Chesner (2012) for a location that we surmise has to be essentially along the same transect, these four ages define a broadly isochronous upper surface relative to the 74 ka history of the lake; the $\sim 5000$ year age spread could be accounted for by local variations in uplift as discussed later. Broadly speaking the data suggest tilting of Samosir with maximum uplift in the east and minimal uplift in the west. The ages indicate that the upper surface of Samosir was submerged and sediments were being deposited ca. 33-28 ky. While the depth of submergence is unknown, a reasonable assumption is that the upper surface of Samosir (the top of the $100 \mathrm{~m}$ sedimentary sequence) was last at lake level $\sim 900 \mathrm{~m}$ a.s.l at this time (Figure 2). The uppermost sediments sampled at Aek Natonang on the eastern scarp by us (sample Toba 5) and Chesner (2012) are from elevations of $1600 \mathrm{~m}$ implying uplift to that elevation since ca. 33.7 ( 1 in Figure 2). This yields an average minimum uplift rate of $2.1 \mathrm{~cm} /$ year for the eastern scarp of Samosir using a lake level datum of $900 \mathrm{~m}$. This is a simple linear rate based on the highest datable sediment; the story is more complex and we present more detailed estimates below. Average uplift rates from sample Toba 6 at Danau Sidihoni at $1305 \mathrm{~m}$, and sample Toba 1 from Salaon Toba at $1035 \mathrm{~m}$ respectively are 1.42 and $0.48 \mathrm{~cm} /$ year consistent with diminishing uplift toward the western edge of Samosir and the western caldera margin resulting in the westward tilt of Samosir.

The upper surface of Samosir is characterized by a succession of normal faults parallel to the length of the island (Figure 5). Relative timing of offsets and cross cutting reveal that these faults occurred in four stages, starting with the primary fault formingthe axial graben along the east of Samosir (Samosir Fault), and ending with broadly parallel faulting of the lake sediments on the western slopes of Samosir (Figure 5). It is clear that the main uplift of Samosir was accommodated by normal faulting stepping down to the east-the Samosir Fault system. 


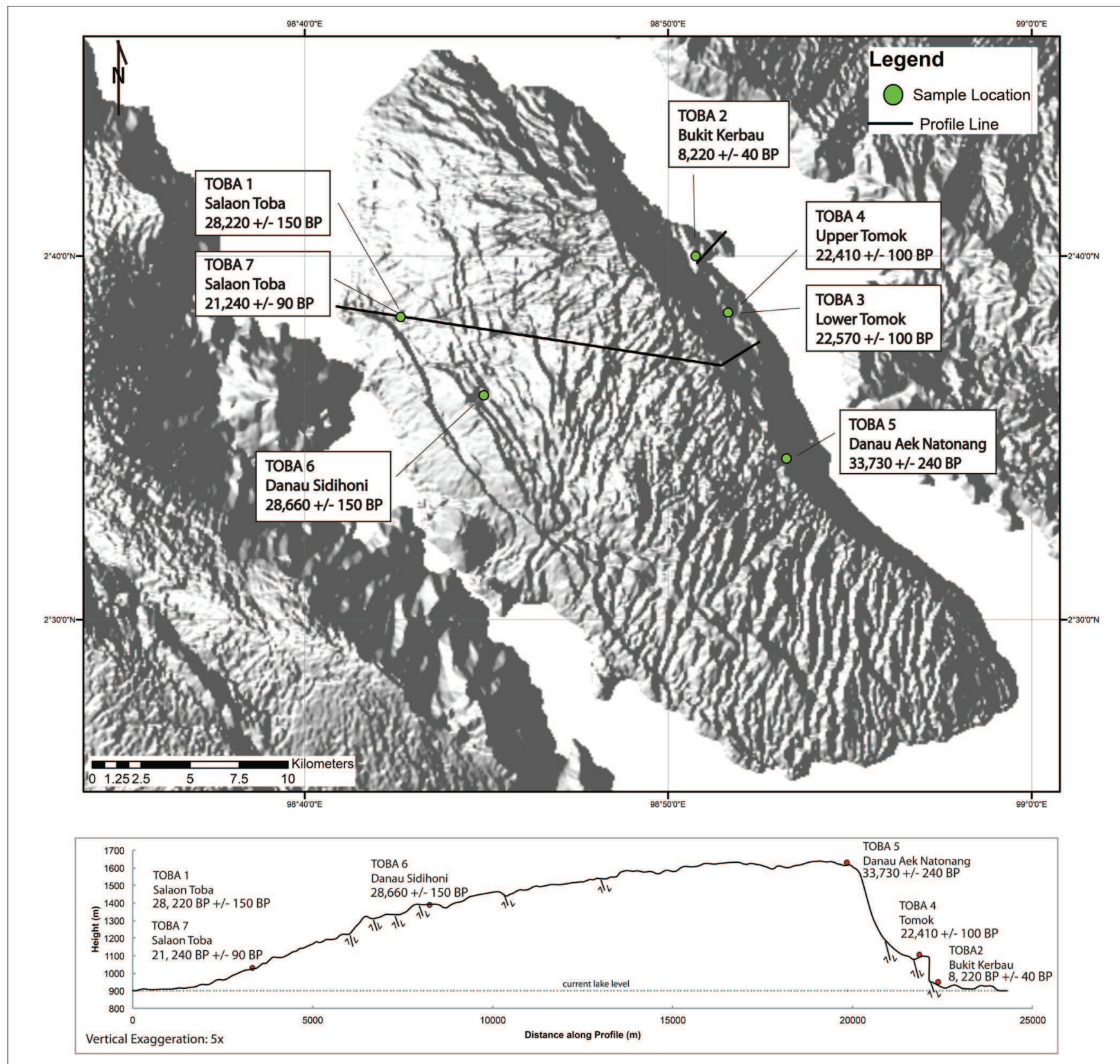

FIGURE 4 | DEM (90 m SRTM, azimuth of light from $270^{\circ}$ ) and topographic profile showing transect across Samosir with our preliminary age data from the uppermost sediments at different elevations. The sample locations are projected on to the line of profile shown below. Location and sense of motion of the major faults that intersect the line of section are also shown.
Shallow normal faults stepping to the east formed during the third stage of faulting and suggest local extension as the resurgent dome was uplifted. This is likely because the western margin of Samosir was a hinge and fixed in position, resulting in extension of the surface of the dome to accommodate the uplift. During this expansion, normal faults parallel to the island formed in the lake sediments. These normal faults cut across antecedent drainage, established when the resurgent dome was being uplifted. Local variations in uplift may have been accommodated by these faults accounting for the $\sim 5000$ year age spread along the transect.

During and subsequent to this primary faulting event, probably throughout Samosir's uplift history, hinge faults formed, branching off the primary fault. Along these hinge faults to the east, blocks of the escarpment have slid down, their upper horizontal surface forming terraces. The local presence of lake sediment covered debris flows and avalanche deposits suggest that these blocks slumped beneath lake level, to be uplifted again. As one traverses down the eastern scarp, two 


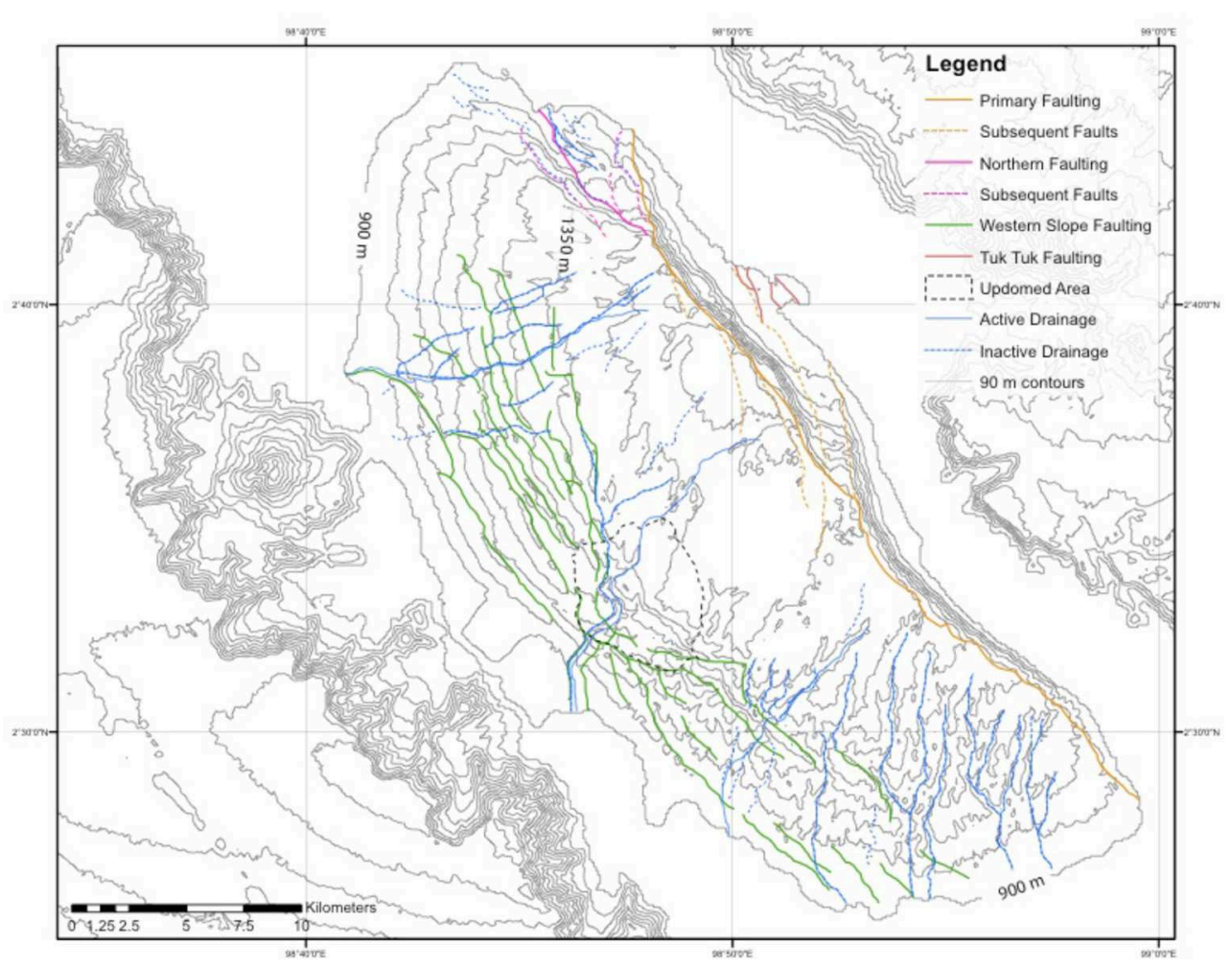

FIGURE 5 | Map of faulting and drainage evolution on Samosir. Stage 1: The main uplift was accommodated by normal faulting stepping down to the east-the Samosir Fault system (Orange). During and subsequent to this primary faulting event, hinge faults formed, branching off the primary fault. Hinge faults on the hanging wall branched up to the north, whereas the faults on the footwall thrown side branched down to the south. Stage II: Subsequent faulting on the north of Samosir (Magenta). Normal faulting along an extension of the primary fault caused blocks to slump along hinge faults, cutting across the established primary drainage system. The drainage system was offset and captured by these hinge faults, creating a secondary drainage system that is currently in place. Stage III: A third stage of faulting (Green) occurred sometime after these initial two stages. This appears to have been preceded by a local uplift (dashed black outline) that clearly affects the orientation and continuity of the faults and drainage. Shallow normal faults stepping to the east (Figure $\mathbf{3 C}$ also) suggest local extension as the resurgent dome was being uplifted. During this expansion, normal faults running parallel to the shape of the island formed in the lake sediments cutting across antecedent drainage. Stage IV: A late stage of faulting occurred in the eastern tip of the island (Red), along with the formation of the Tuk Tuk lava dome. The relationship between faulting and eruption is unknown, but the presence of lake sediments on part of the upfaulted block suggests that $\sim 8 \mathrm{ka}$ this area was underwater. Whether this implies a subaqueous dome and pyroclastic apron that was later uplifted is unknown. locations where these surfaces are prominent are at Tomok and on the Tuk Tuk peninsula. In the case of Tuk Tuk this was predominantly the upper surface of lava dome extrusions. Ages of wood fragments in sediment at Tomok (samples Toba 3 and $4 ; \sim 1050 \mathrm{~m}$ ) and organic-rich sediment at Tuk Tuk (Bukit Kerbau; sample Toba 2; $955 \mathrm{~m}$ ) are 22,410 \pm 100 and 8,220 \pm 40 years ago, respectively (Figure 4), implying that these surfaces were submerged at this time. We interpret these two locations as recording the continued uplift of Samosir at $\sim 22.5$ and $8.2 \mathrm{ka}$.

\section{Long Term Rates of Uplift of Samosir}

It is clear that Samosir has a rich neotectonic history in its drainage and fault network. Abundant debris flows, unconformities and faulting attest to a complex history of uplift and sedimentation. These complications notwithstanding, the
${ }^{14} \mathrm{C}$ age data obtained from the transect over Samosir provide useful information to investigate the uplift history of Samosir. Our data only provide constraints from $\sim 33.7 \mathrm{ka}$ to the present, and we now examine the history of uplift revealed by these data.

The data (samples Toba 1,5,6 and 7) from the transect of the upper surface of Samosir are consistent with tilting hinged in the west and uplift focused on the east. Data from the eastern scarp (samples Toba 2,3,4 and 5) reveal that uplift of Samosir has happened at varying rates over time (Figure 6). With our lake level datum of $\sim 900 \mathrm{~m}, 700 \mathrm{~m}$ of uplift is recorded by the sediments at the highest elevation of $1600 \mathrm{~m}$ that yielded an age $33.7 \mathrm{ka}$. We consider this as the total cumulative uplift because $\sim 150 \mathrm{~m}$ of uplift is recorded in sediments of $22.5 \mathrm{ka}$ and another $55 \mathrm{~m}$ in the sediments of $8.2 \mathrm{ka}$. This is based on our interpretation stated above that the Tomok and Tuk Tuk blocks are fault slivers that slid down off the uplifting main block and were submerged. In the case of Tuk Tuk this would have 


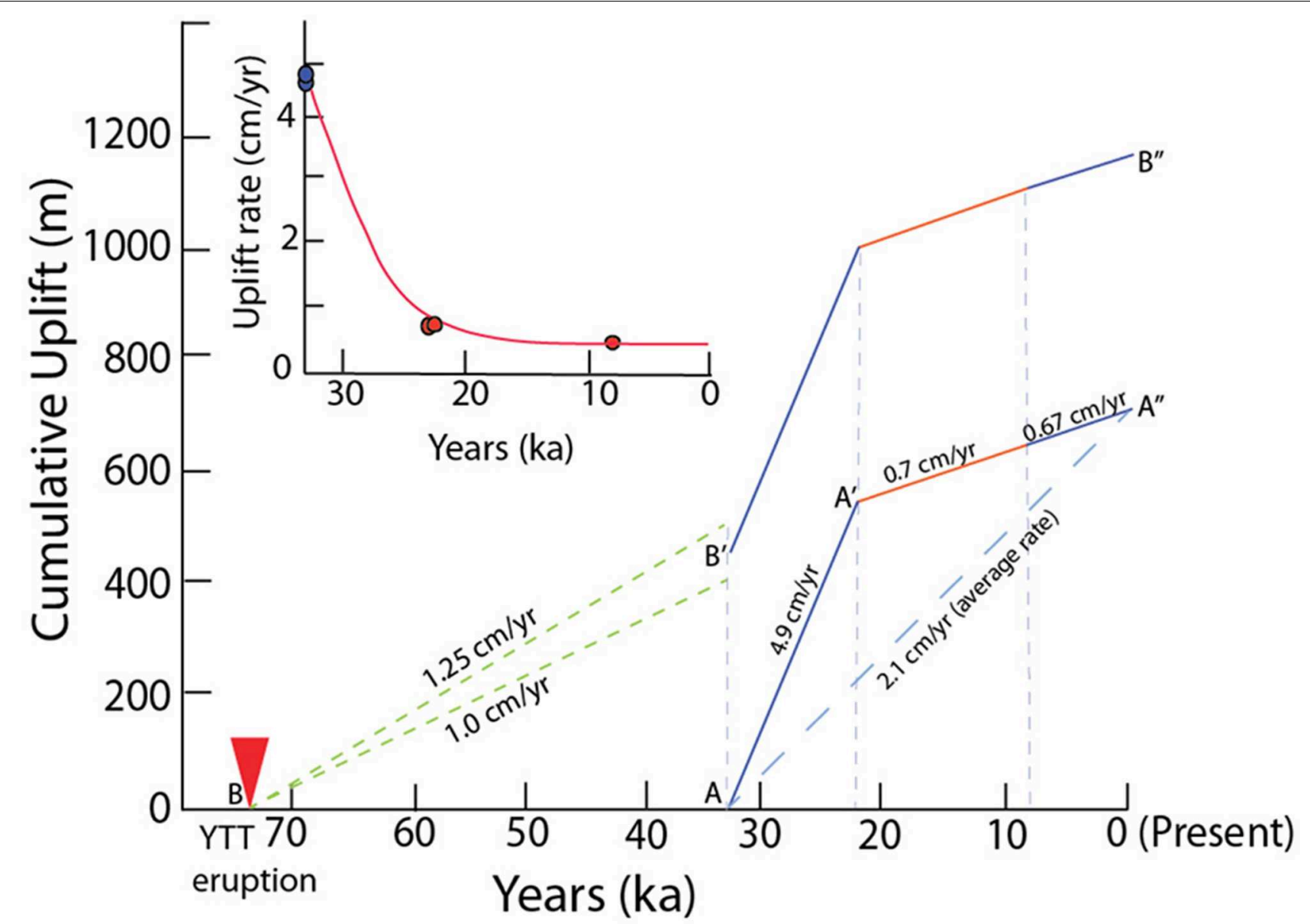

FIGURE 6 | Representation of the various uplift parameters calculated for Samosir. The main figure shows cumulative uplift (elevation gain with time) of the eastern scarp of Samosir based on ${ }^{14} \mathrm{C}$ age determinations and current elevation above lake level datum $\sim 900 \mathrm{~m}$. $A-A-A^{\prime \prime}$ represents the $C^{14}$ data constrained cumulative uplift path defined by samples (Toba 2,3,4, and 5 on Figure 4). The dashed blue line connecting $A-A^{\prime \prime}$ is the average rate based on the elevation and age of the highest $(\sim 1600 \mathrm{~m})$ sediment on Samosir. B-B' $-B^{\prime \prime}$ is the cumulative uplift history if the period prior to $33.7 \mathrm{ka}$ is considered in this case starting at the time of the climactic eruption $74 \mathrm{ka}$. Note that $\mathrm{B}^{\prime}-\mathrm{B}^{\prime \prime}$ is simply $A-\mathrm{A}^{\prime}-\mathrm{A}^{\prime \prime}$ translated to start after uplift from 74 to $33.7 \mathrm{ka}$ has taken place. The dashed green lines B-B' represents possible uplift rates of 1.25-1.0.cm/year if the floor was at elevation of $400 \mathrm{~m}$ a.s.I (500 $\mathrm{m}$ of uplift) or takes into account $100 \mathrm{~m}$ of sediment thickness ( $400 \mathrm{~m}$ of uplift). Inset shows our interpretation of how uplift rates may have diminished over time from $33.7 \mathrm{ka}$ to present based on the ${ }^{14} \mathrm{C}$ data and sample elevations as discussed in the text. been sometime after the domes were extruded. Their eventual uplift is interpreted to have been in parallel with and linked to continuing uplift of the main Samosir block and they emerged above lake level at $22.5 \mathrm{ka}$ and $8.2 \mathrm{ka}$ respectively. We prefer this interpretation to one where each block has a distinct and independent uplift history. This might be reasonable if the uplift was local tectonics, but below we present the case for a magmatic drive for resurgent uplift and in this context the uplift of these slumped blocks, would be linked to the uplift of the main block because the magmatic force is unlikely to be discretized at the scale of these blocks. Thus, in our view, once the Tomok and Tuk Tuk blocks began to uplift they record the rate at which the main block was also uplifting from 22.5 to present.

On this basis we break down the uplift of Samosir into three stages (Table 2): $545 \mathrm{~m}$ of the uplift in the first stage from 33.7 to $22.5 \mathrm{ka}, 100 \mathrm{~m}$ of uplift from 22.5 to $8.2 \mathrm{ka}$, and finally $55 \mathrm{~m}$
TABLE 2 | Uplift and uplift rates for Samosir, Toba since 33.7 ka.

\begin{tabular}{lccc}
\hline Age range & Time interval (ka) & Uplift (m) & Uplift Rate (cm/year) \\
\hline $33.7-22.5 \mathrm{ka}$ & 11.2 & 545 & 4.9 \\
$22.5-8.2 \mathrm{ka}$ & 14.3 & 100 & 0.7 \\
8.2 ka to present day & 8.2 & 55 & 0.7 \\
33.7 ka to present day & 33.7 & 700 & 2.1
\end{tabular}

of uplift from $8.2 \mathrm{ka}$ to present. These stages reveal uplift in the first $11.2 \mathrm{ka}$ of an average of $4.9 \mathrm{~cm} /$ year that diminishes to $0.7 \mathrm{~cm} /$ year from $22.5 \mathrm{ka}$ to the present (through another data point at $8.2 \mathrm{ka}$ ). These data provide better temporal resolution of the evolution of uplift than the single data point from $\sim 1600 \mathrm{~m}$. Total uplift over time gives $2.1 \mathrm{~cm} /$ year (our data for the upper 
surface discussed above and Chesner's single (2012) data point adjusted to our lake level datum), but this is an averaged minimum (Figure 6). The identification of three different periods of uplift helps us define diminishing rates of uplift, which while minima, provide the first real constraints on long term uplift rates at a large caldera and provide a basis with which to explore the likely mechanisms of resurgence. It is possible that locally, shortterm $\left(10^{0}-10^{2}\right.$ years $)$ rates may have been much higher, similar to currently restless calderas.

\section{Modeling Resurgence at Toba}

Despite the recognition of resurgence as a critical stage in the caldera cycle, very few efforts have tried to unravel the mechanics and timing of caldera resurgence. The most notable modeling study is the analytical investigation of Marsh (1984), which discusses four hypotheses for resurgence: (1) detumescence; (2) hydrostatic rebound; (3) magma flux; and (4) magma pressure. As Marsh (1984) indicates, hydrostatic rebound can be ruled out due to its short timing, leaving detumescence and magmatic processes as two competing hypotheses. While an analytical approach such as developed by Marsh (1984) can provide important first-order insights, it is severely limited by the assumptions underlying it. For example, in the case of the mechanism of magmatic pressure, the Marsh (1984) model assumes the base of the caldera is pinned, the uplift is purely sinusoidal, and the rate of resurgence is a function of crustal viscosity. This solution does not account for the magma reservoir geometry (including magmatic source depth or size) nor does it allow for an assessment of magmatic flux rates, both of which greatly affect the timing of resurgence. These limitations result in the inability to use the Marsh (1984) approach to resolve between detumescence and magmatic processes as the driving mechanism of resurgence. Furthermore, because of their simplicity, the Marsh (1984) models provide no information regarding the stress state of the host material and how that evolves during resurgence. This consideration is critical in particular for an investigation of magmatic processes as the intrusion rate and depth must result in resurgence rather than eruption.

As such, a numerical finite element model (FEM) approach is necessary to investigate resurgent timing in greater detail. Previous numerical investigations using elastic finite element models indicate magmatic initiation via intrusion along a ring dike may promote resurgent uplift observed at caldera systems (Saunders, 2001, 2004). However, while these models illustrate the elastic response due to magmatic intrusion, they do not provide means to calculate uplift rates. Resurgence as a result of detumesence has been investigated numerically by Chery et al. (1991) who utilize a temperature-dependent viscoelastic FEM to investigate the passive relaxation process, or detumescence, after caldera formation. Their models provide calculations of the timing of resurgence, which is governed by host-rock viscosity, i.e., the viscoelastic relaxation time. However, passive resurgence for an end member model with complete caldera excavation and a "hot" low viscosity host rock produces a resurgence rate of $\sim 0.6 \mathrm{~cm} /$ year, which is much less than the initial average of $4.9 \mathrm{~cm} /$ year we have determined for the 33.7-22.5 ka period of uplift at Samosir. Furthermore, Chery et al. (1991) find that (without increasing the gravitational loading to unrealistic levels) there is only minimal uplift due to resurgence, $<10 \mathrm{~m}$. As mentioned above, Chery et al. (1991) did not investigate any other mechanisms for resurgence such as magmatic processes, which occur on shorter timescales than detumescence, nor did they incorporate failure criteria, stress evolution of the system during resurgence, or geometrical variations. So, while the Chery et al. (1991) study provides a starting point for investigating passive resurgence models, their work raises many questions including the effect of loading due to the variations in caldera geometry (e.g., trapdoor vs. uniform collapse), caldera infill by lower density ignimbrite or water during lake formation, as well as the effect of more complex crustal rheologies.

One important finding of the preliminary models (Marsh, 1984; Chery et al., 1991) is that the timing of passive resurgence such as detumescence is directly linked to the rheology of the host material. In other words, the viscoelastic relaxation time is critical for determining the timing of the response of the host material. Thus, by investigating end-member rheological models we should be able to place first-order constraints on the effects of detumescence and potentially rule out or confirm this as the primary mechanism for resurgence. On the other hand, magma influx has a different temporal signature. The uplift response due to the influx of magma is on a much shorter timescale, i.e., the timescale of magmatic recharge. The evolution of uplift rates provided by analysis of lake sediments from Toba Caldera allows us to make predictions for how much (if any) magmatic influx is required to produce the observed uplift rates. We recognize that these predictions do not take into account recharge operating on timescale of $10^{0}-10^{2}$ years.

Taking advantage of previous advances in thermomechanical modeling of calderas (Gregg et al., 2012, 2013), we utilize COMSOL Multiphysics 4.4 in combination with MATLAB 2014b to develop and implement a temperature-dependent, viscoelastic FEM for a resurgent caldera (Figures 7, 8). COMSOL is utilized for mesh development (including adaptive meshing), and solving for stress, strain, and displacement in response to applied loads in a linear viscoelastic solid using a Maxwell-Weichert formulation. COMSOL also solves for heat transfer using the first law of thermodynamics, where mass, momentum, and energy are conserved. The parameters that are most critical for the model results are caldera and magma reservoir geometry and crustal viscosity. The variable that has the greatest effect on predicted resurgent uplift is reservoir volume change, $\Delta \mathrm{V}$, which is calculated from magmatic flux (e.g., Gregg et al., 2013). Thus, of particular interest are the combined effects of magma intrusion $(\Delta \mathrm{V})$ and the detumescence caused by caldera excavation and the resultant caldera topography.

As indicated by previous investigations (e.g., Chery et al., 1991), the parameter that has the greatest effect on resurgence time due to detumescence is host rock viscosity. Uplift due to magma chamber growth is also highly dependent on crustal rheology (Del Negro et al., 2009; Gregg et al., 2012, 2013). We investigate two end-member cases for the crustal rheology: constant viscosity and temperature-dependent viscosity. The first assumes that viscosity is constant (i.e., isoviscous) and that 


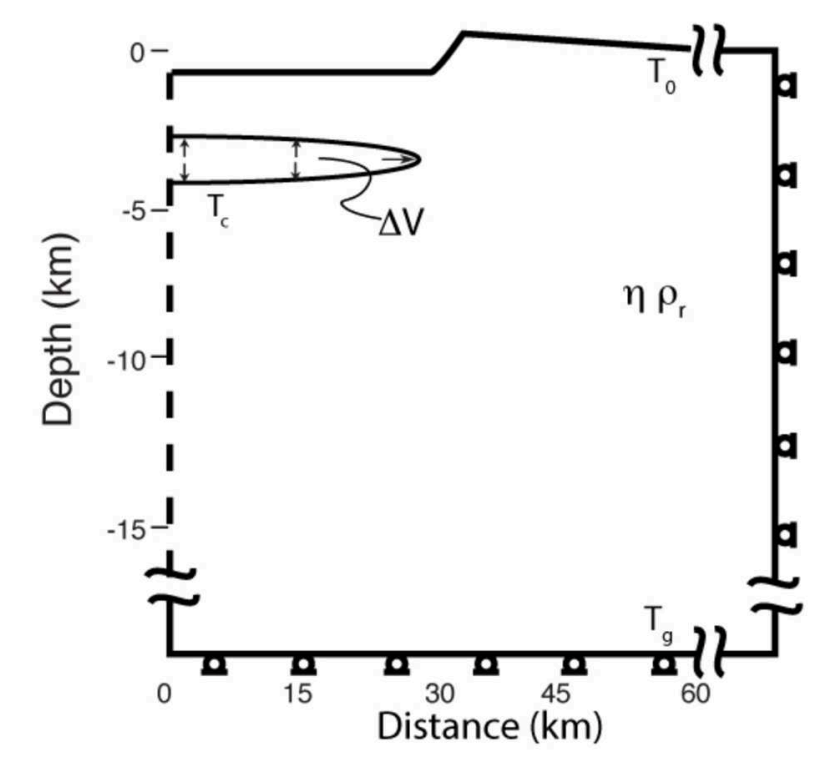

FIGURE 7 | Model setup illustration for a $1 \mathrm{~km}$-deep post-collapse caldera with a radius of $30 \mathrm{~km}$ a circular approximation of the area of

Toba Caldera. The left boundary condition is axial symmetry, the top of the model is free to deform, as is the magma reservoir boundary, and zero displacement, roller conditions are implemented along the right and bottom boundaries. The temperature of the magma reservoir $\left(T_{C}\right)$ is defined along the magma reservoir boundary, $T_{0}=0^{\circ} \mathrm{C}$ is defined at the surface of the model, and an initial background geotherm $\left(T_{g}=30^{\circ} \mathrm{C} / \mathrm{km}\right)$ is assumed. The temperature-dependent rheology assumes steady state thermal structure as an end-member for full thermal impact of a long-lived magma reservoir. Because steady-state temperature-dependence is an end-member situation, it is compared to the alternate end-member of a non temperature-dependent isoviscous model. Model setup includes caldera resurgence topography due to detumescence as well as recharge into a shallow magma reservoir. $\Delta \mathrm{V}$ of magma intrusion into the magma reservoir is approximated by a pressurized void.

there is no thermal contribution from the magmatic system. This is unlikely as the process of building a large silicic system requires thermal preparation of the host rock (e.g., de Silva and Gosnold, 2007; de Silva and Gregg, 2014). However, the isoviscous case provides one end-member. The alternative endmember is one that incorporates the full thermal impact of the magmatic system and assumes that the magma reservoir has a steady-state impact on the thermal structure as shown in de Silva and Gregg (2014). This represents the absolute maximum thermal impact of the magma system. Since we are exploring these two end-member models, we have chosen $900^{\circ} \mathrm{C}$ for magmatic temperature to represent an upper end-member for thermal input. The true thermal impact from the magma chamber is likely to be somewhere in between these two models, but this approach provides a first order constraint.

A series of resurgent models have been run to investigate the effect of both detumescence and $\Delta \mathrm{V}$ for a resurgent caldera of approximately the size of Toba Caldera. Because the models are pseudo $3 \mathrm{D}, 2 \mathrm{D}$ axisymmetric models, the caldera is assumed to be circular with a radius of $30 \mathrm{~km}$ to approximate the area of the Toba caldera. This provides a first-order estimate for

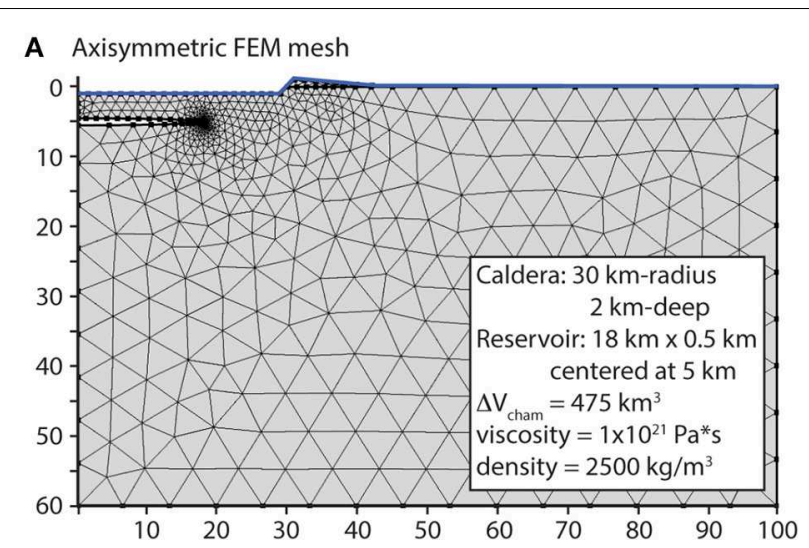

B Surface displacement [m], at 50 kyrs

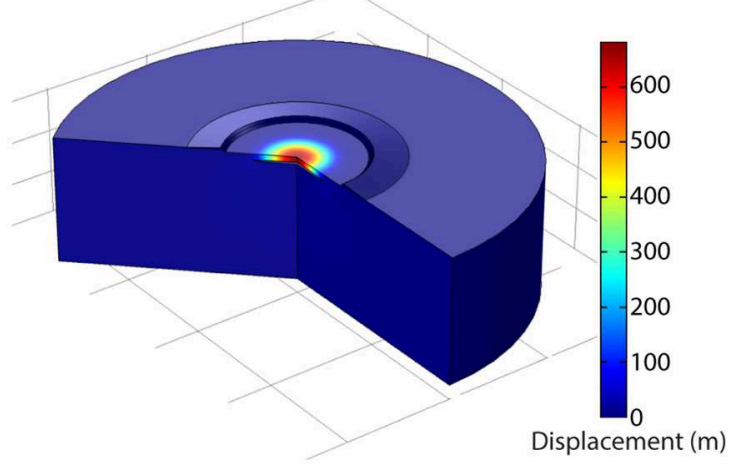

FIGURE 8 | Model mesh (A) and displacement (B) for $475 \mathrm{~km}^{3}$ of magmatic recharge into a host rock with a constant viscosity rheology, $\eta_{r}=1 \times 10^{21}$ Pa s. Maximum surface uplift is $\sim 700 \mathrm{~m}$.

uplift to compare to the ${ }^{14} \mathrm{C}$ age data. Our model calculates the effect of a volume change in a shallow reservoir. This $\Delta \mathrm{V}$ could be due to re-establishing magmastatic equilibrium after the caldera collapse as remnant magma "intrudes" into shallower levels due to rebound or this could be due to a background magma flux recharging the system or a combination of both.

Two model suites have been run. The first calculates resurgent uplift from detumescence alone and assumes constant viscosity host rock with no thermal input from the magma chamber, and the second combines detumescent uplift with a magma reservoir expansion event assuming full thermal impact from the magma chamber. In the detumescent model, the host-rock is assumed to have a constant viscosity of $10^{21} \mathrm{~Pa}$ s, and a shallow crustal magma chamber centered at $3.5 \mathrm{~km}$-depth with a radius of $18 \mathrm{~km}$ is assumed with a viscosity of $10^{9} \mathrm{~Pa}$ s (Table 3). The geologically instantaneous formation of a $2 \mathrm{~km}$-deep caldera is assumed at $\mathrm{t}_{0}$, $74 \mathrm{ka}$, and resurgence is calculated as the system detumesces and re-equilibrates. For the resurgent response due to detumescence, for a viscosity of $10^{21} \mathrm{~Pa} \mathrm{~s}$, the maximum resurgent uplift of $18 \mathrm{~m}$ is reached after $\sim 30 \mathrm{ky}$ (Figure 9A, inset). Hence, the timing and magnitude of resurgent uplift due to detumescence does not reproduce the observations from Toba Caldera. While the time scale of uplift and its decay are reasonable, the amount of uplift 
TABLE 3 | Model parameters used in applying the Gregg et al. (2012) thermomechanical approach to this investigation of resurgence.

\begin{tabular}{|c|c|c|}
\hline Parameter & Description & Value \\
\hline$A_{D}$ & Dorn Parameter, Pa s & $10^{9}$ \\
\hline C & Cohesion, $\mathrm{Pa}$ & $10^{6}$ \\
\hline$C_{P}$ & Specific heat capacity, $\mathrm{J} \mathrm{kg}^{-1} \mathrm{~K}^{-1}$ & $1.25 \times 10^{3}$ \\
\hline$D$ & $\begin{array}{l}\text { Depth to center of magma reservoir, } \\
\mathrm{km}\end{array}$ & 3.5 \\
\hline E & $\begin{array}{l}\text { Young's modulus in elastic model } \\
\text { runs, } \mathrm{Pa}\end{array}$ & $75 \times 10^{9}$ \\
\hline$E_{T d}$ & $\begin{array}{l}\text { Temperature-dependent Young's } \\
\text { modulus, } \mathrm{Pa}\end{array}$ & $10 \times 10^{9}, T>650^{\circ} \mathrm{C}$ \\
\hline$E_{A}$ & Activation Energy, $\mathrm{J} \mathrm{mol}^{-1}$ & $1.2 \times 10^{5}$ \\
\hline G & Shear modulus, $\mathrm{E} /\left(2^{*}(1+v)\right), \mathrm{Pa}$ & $50 \times 10^{9}$ \\
\hline$G_{T d}$ & $\begin{array}{l}\text { Temperature-dependent shear } \\
\text { modulus }\end{array}$ & $6.67 \times 10^{9}, T>650^{\circ} \mathrm{C}$ \\
\hline K & Bulk modulus, $\mathrm{E} /\left(3^{*}\left(1-2^{\star} v\right)\right), \mathrm{Pa}$ & $30 \times 10^{9}$ \\
\hline$K_{T d}$ & $\begin{array}{l}\text { Temperature-dependent bulk } \\
\text { modulus }\end{array}$ & $4 \times 10^{9}, T>650^{\circ} \mathrm{C}$ \\
\hline$\eta_{r}$ & Host rock viscosity, Pa s & $1 \times 10^{21}, 2.5 \times 10^{21}, 5 \times 10^{21}$ \\
\hline$\eta_{m}$ & Magma viscosity, Pa s & $1 \times 10^{9}$ \\
\hline$\mu_{0}, \mu_{1}$ & Fractional shear modulus & 0.5 \\
\hline$v$ & Poisson's ratio & 0.25 \\
\hline$R$ & Universal gas constant, $\mathrm{J} \mathrm{kg}^{-1} \mathrm{~K}^{-1}$ & 8.3114 \\
\hline$r_{C}$ & Caldera radius, km & 30 \\
\hline$r_{r}$ & Reservoir radius, $\mathrm{km}$ & 18 \\
\hline $\operatorname{\rho r}$ & Host rock density, $\mathrm{kg} \mathrm{m}^{-3}$ & 2500 \\
\hline$\rho m$ & Magma density, $\mathrm{kg} \mathrm{m}^{-3}$ & 2500 \\
\hline$T_{0}$ & Surface temperature, $\mathrm{K}$ & 273.15 \\
\hline$T_{m}$ & Magma reservoir temperature, $\mathrm{K}$ & 1173.15 \\
\hline$\Delta V$ & $\begin{array}{l}\text { Magma reservoir volume change, } \\
\mathrm{km}^{3}\end{array}$ & 475 \\
\hline
\end{tabular}

is orders of magnitude too small; only $\sim 18 \mathrm{~m}$ of uplift can be attributed to detumescence in our models.

The second suite of models assumes a volume change event in the reservoir between $42.5 \mathrm{ka}$ and $33.7 \mathrm{ka}$. The mechanism for the volume change is not specified and as stated above could be recharge or magma rebound of non-erupted portions of the climactic magma or both. The volume change is assumed to be a single, pulse of incompressible magma entering a shallow magma reservoir with a radius of $18 \mathrm{~km}$ centered at $5 \mathrm{~km}$-depth. The timing of the pulse has been varied to provide the best fit for the given viscosity. Specifically, the volume change, $\Delta \mathrm{V}$, models assume a single pulse of magma at $33.7 \mathrm{ka}$ for the temperaturedependent viscosity model, $36 \mathrm{ka}$ for the $1 \times 10^{21} \mathrm{~Pa}$ s viscosity case, at $39.25 \mathrm{ka}$ for the $2.5 \times 10^{21} \mathrm{~Pa}$ s viscosity case, and $42.5 \mathrm{ka}$ for the $5 \times 10^{21} \mathrm{~Pa}$ viscosity. Viscosity impacts the viscoelastic relaxation of the system, with higher viscosity resulting in a longer the timescale viscoelastic relaxation. The time of the onset of the magmatic pulse is varied such that the the predicted viscoelastic relaxation timescales for the different viscosities best match those observed in the data. The single pulse volume change models are compared to a model with a constant magma flux of $0.0064 \mathrm{~km}^{3} /$ year (gray solid line in Figure 9). In these models, we find that a single pulse of $475 \mathrm{~km}^{3}$ of incompressible magma coupled with the temperature dependent viscosity and an isoviscous model with a viscosity of $10^{21} \mathrm{~Pa}$ s provide the best fit to the cumulative uplift data (Figure 9A). However, these same models do not quite match the uplift rates (Figure 9B). While the same single pulse models can be fit to the uplift rates in Figure 9B if a greater volume change was used, then the volume change would not fit the cumulative uplift data. So we cannot identify a unique combination of $\Delta \mathrm{V}$ and viscosity that will explain both data representations successfully. This may not be unexpected given that there are limited data to constrain the models and these are relatively simple models that do not account for multiple pulses. Nonetheless the models clearly distinguish between detumescence and magma reservoir volume change as the motivating process for uplift. A minimum $\Delta \mathrm{V}$ of $475 \mathrm{~km}^{3}$ is required to account for the uplift data. A constant magma flux does not reproduce any of the observations, and this model run is provided for comparison purposes. In particular, while the constant magma flux model could reproduce the magnitude of observed uplift, it does not capture the accumulation of that uplift nor the exponential roll-off of the uplift rate with time.

Additional complexities include how magma compressibility may impact these modeling results. As mentioned above, the volume change of the reservoir could be due to any number of factors such as magma intrusion from below, or magmastatic readjustment after the climactic eruption (rebound). It is thought that following the climactic caldera-forming event, the magma reservoir is significantly degassed and unlikely to be volatile saturated. However, gas phases may increase compressibility within the system. As such, it is important to note that the volume change calculated by our models is a total volume of expansion experienced by the magma reservoir, and may not simply reflect an intrusion volume if the intruding material is volatile rich and highly compressible. To address this requires new models of multiphase magma injection. Compressibility of the magma in the reservoir and of the injected magma do not impact the uplift rates, as these curves are governed by the viscosity of the host rock. Compressibility will impact the amount of material necessary to produce the observed uplift. As such, $475 \mathrm{~km}^{3}$ of volume change represents a minimum amount assuming no compressibility.

Compressibility also plays a role in the amount of uplift predicted from detumescence where there is a remnant magma body present. The detumescence model runs presented in Figure 9 include compressibility of the magma, which is controlled by its material properties (i.e., the elastic moduli). In the case of the detumescence models presented in Figure 9, compressibility is modest and governed by assumed values of the elastic moduli. Increasing the compressibility by, for example decreasing Young's modulus, acts to dampen the effects of detumescence and decrease the predicted uplift. For reasonable ranges in elastic moduli, increasing compressibility may decrease the predicted uplift due to detumescence by as much as half, to $5-10 \mathrm{~m}$. As with the volume change scenario, the timing of the uplift remains the same regardless of compressibility, because it is governed by the host rock viscosity. 

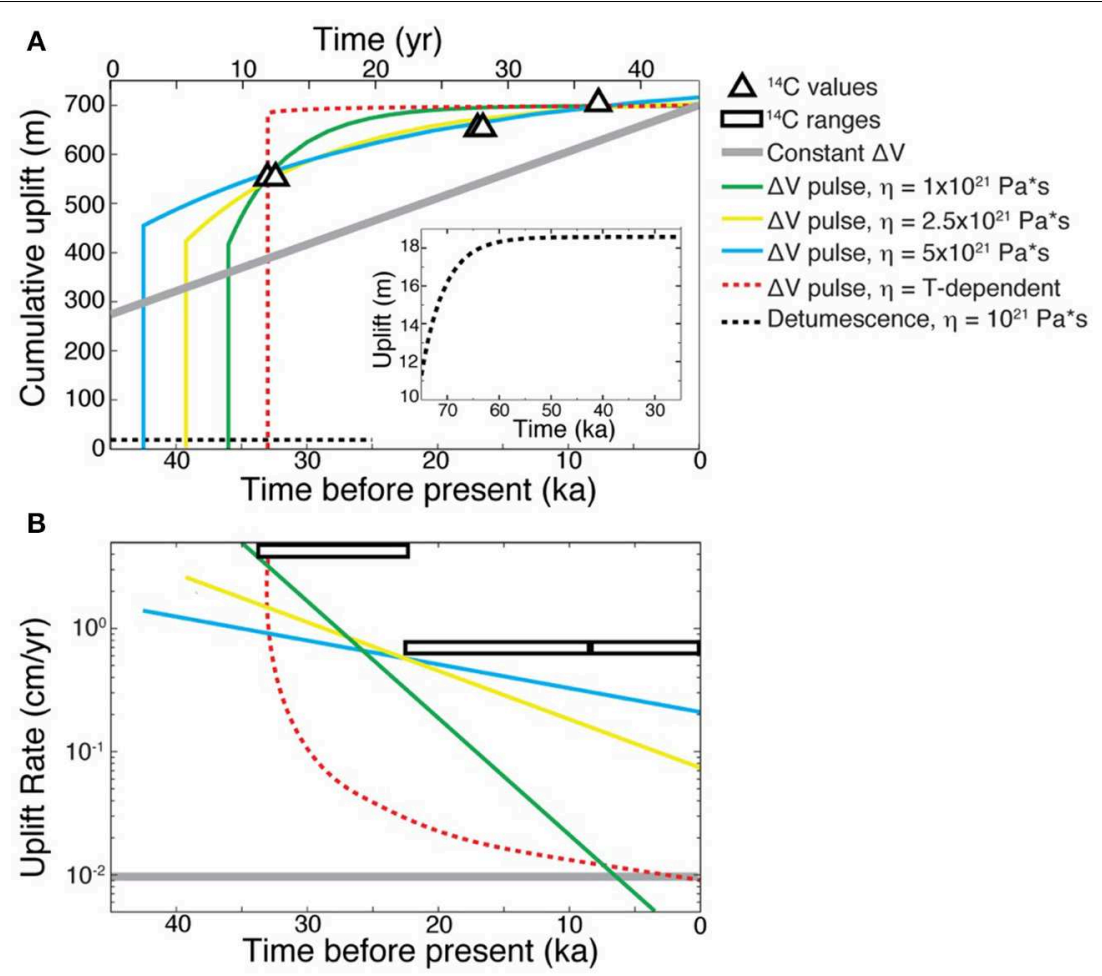

FIGURE 9 | Model calculations of (A) uplift and (B) uplift rate for several resurgent models including. Detumescence, isostatic rebound (dashed black line), constant volume change $\left(\Delta \mathrm{V}=0.0064 \mathrm{~km}^{3} /\right.$ year $)$ into a viscoelastic host rock (gray line), a single volume change ( $\Delta \mathrm{V}=$ $475 \mathrm{~km}^{3}$ ) pulse into a viscoelastic host rock with a specified constant viscosity (green, yellow, and blue solid lines), and a single volume change pulse ( $\Delta \mathrm{V}=475 \mathrm{~km}^{3}$ of magma) into a viscoelastic host rock with a temperature dependent rheology, assuming a $900^{\circ} \mathrm{C}$ magma chamber boundary (red, dashed line). Uplift and uplift rates derived from
${ }^{14} \mathrm{C}$ dates are indicated by white triangles and the white rectangles respectively. While detumescence related uplift (inset of $\mathbf{B}$ ) operates on a similar timescale to the uplift due to volume change, the uplift rate due to detumescence is significantly lower than that of the volume change, with the maximum uplift of $9 \mathrm{~m}$ being reached about $10 \mathrm{ky}$ after onset. Volume change, $\Delta \mathrm{V}$, models assume a single pulse of magma at $33.7 \mathrm{ka}$ for the temperature-dependent viscosity, $36 \mathrm{ka}$ for the $1 \times 10^{21} \mathrm{~Pa} s$ viscosity, at $39.25 \mathrm{ka}$ for the $2.5 \times 10^{21} \mathrm{~Pa} \mathrm{~s}$ viscosity and $42.5 \mathrm{ka}$ for the $5 \times 10^{21} \mathrm{~Pa} \mathrm{~s}$ viscosity.

\section{Early Resurgence from 74 to $33.7 \mathrm{ka}$}

Our data discussed above provide constraints on the uplift history of Samosir from $\sim 33.7 \mathrm{ka}$. However, there must have been uplift before that. The caldera floor was apparently $500 \mathrm{~m}$ deeper than current lake level at $400 \mathrm{~m}$ a.s.l. (Figure 2), so there had to be $500 \mathrm{~m}$ of uplift before the caldera floor started to appear above the lake surface. In fact Chesner (2012) has estimated the total uplift of Samosir to be $1100 \mathrm{~m}$, if the $100 \mathrm{~m}$ of sediment is subtracted. We have only accounted for $700 \mathrm{~m}(900 \mathrm{~m}$ lake level to $1600 \mathrm{~m}$ top of the sediment) of that history. Chesner (2012) presents the possibility that resurgence may have been ongoing since $74 \mathrm{ka}$ and calculated a minimum rate of $1.5 \mathrm{~cm} /$ year $(1100 \mathrm{~m} / 74 \mathrm{ka})$. This is not without merit. The only age data that speak to the post-YTT to $33.7 \mathrm{ka}$ period is the age data of the Samosir Lava Domes that Chesner (2012) reports as "indistinguishable from the age of the YTT (75-77 ka)." If this is correct, resurgence may have started soon after the YTT eruption. We develop this as a strawman hypothesis but only consider the 74-33.7 ka period here, having constrained the 33.7 ka history above.

Five hundred meters of uplift in $\sim 40$ ka yields an average uplift rate of $1.25 \mathrm{~cm} /$ year. However, since there is $100 \mathrm{~m}$ of sediment on Samosir, this needs to be taken into account, so less than $500 \mathrm{~m}$ of uplift is needed for the uppermost sediment to get to lake level. If we assume the simplest case that all sedimentation was complete before uplift started this yields a minimum uplift rate of $1.0 \mathrm{~cm} /$ year $(400 \mathrm{~m} / 40 \mathrm{ka})$. A more accurate calculation would be to consider uplift and sedimentation happening in parallel, but this requires knowledge of sedimentation rates.

Two estimates of sedimentation rates can be derived from our data. Two samples from Salaon Toba that are at elevations of $1035 \mathrm{~m}$ and $1041 \mathrm{~m}$ in elevation respectively yield stratigraphically consistent ages of $28,220 \pm 150$ (Toba 1 Table 1 and Table S1) and 21,240 \pm 90 (Toba 7 Table 1 and Table S1). These data suggest minimum sedimentation rates of 6 meters of sediment in $\sim 7 \mathrm{ka}$, or sedimentation rates of $0.08 \mathrm{~cm} /$ year $(0.8 \mathrm{~mm} /$ year $)$. At Tomok two samples separated by $30 \mathrm{~cm}$ yielded ages of $22570 \pm 100$ (Toba 3 Table 1 and Table S1) and $22410 \pm 100$ (Toba 4 Table 1 and Table S1) for the lower and upper samples respectively. These data result in minimum sedimentation rates of $0.2 \mathrm{~cm} /$ year ( $2 \mathrm{~mm} /$ year). These two estimates suggest $100 \mathrm{~m}$ of sediment would require between $\sim 125$ and $50 \mathrm{ka}$, much longer than the $40 \mathrm{ka}$ constraint placed by the $\mathrm{C}^{14}$ ages. The $0.8-2 \mathrm{~mm} /$ year 
sedimentation rates are consistent with long-term sedimentation rates in lakes in volcanically and tectonically active areas such as Lake Chalpas, Guatemala, and Lake Baikal in Siberia (Edgington et al., 1991; Fernex et al., 2001; Colman et al., 2003), with $2 \mathrm{~mm} /$ year being at the extreme. Thus, these are reasonable sedimentation rates, but they require more than $40 \mathrm{ka}$ to build the $\sim 100 \mathrm{~m}$ sequence of sediments on Samosir. This leaves two possibilities: either the long term sedimentation rates at Toba were much higher than long-term rates at comparable lakes, or some thickness of sediment predates the 74 ka eruption.

Resolution of these possibilities is not currently possible, so at this stage we use the $1.25 \mathrm{~cm} /$ year and $1 \mathrm{~cm} /$ year rates to bracket the average minimum rate of uplift that Samosir was uplifted from 74 to $33.7 \mathrm{ka}$. This results in an intriguing inflection at $\mathrm{B}^{\prime}$ in Figure 6, where the pre-33.7 ka average rate of $\sim 1.12 \mathrm{~cm}$ /year transitions to the $33.7-22.5 \mathrm{ka}$ rate of $4.9 \mathrm{~cm} /$ year; this represents a $\sim 5$-fold increase in the rate of uplift. We consider this an intriguing and realistic scenario. If the 74-33.7 ka rate was also $4.9 \mathrm{~cm} /$ year then the $500-400 \mathrm{~m}$ of uplift discussed above would have been achieved in $\sim 10-8 \mathrm{ka}$ respectively, requiring sedimentation rates as high as $1-1.25 \mathrm{~cm} /$ year or $10_{-}$ $12.5 \mathrm{~mm} /$ year to produce the $100 \mathrm{~m}$ of sediment on Samosir before it emerged. Such rates are up to two orders of magnitude higher than sedimentation rates in the aforementioned lakes (Edgington et al., 1991; Fernex et al., 2001; Colman et al., 2003). We therefore consider uplift at the $33.7-22.5 \mathrm{ka}$ rate of $4.9 \mathrm{~cm}$ /year untenable for the $74-33.7 \mathrm{ka}$ period as it would require unrealistic sedimentation rates for Lake Toba. However, if the uplift rate for the $74-33.7 \mathrm{ka}$ period was $1.12 \mathrm{~cm} /$ year (Figure $6 \mathrm{~B}-\mathrm{B}^{\prime}$ ), the sedimentation rate would be $0.25 \mathrm{~cm} /$ year or $2.5 \mathrm{~mm} /$ year $(100 \mathrm{~m} / 40 \mathrm{ka})$, closer to our maximum rate calculated above from Tomok and the highest sedimentation rates reported from Lake Chapala near pro-delta slopes there (Fernex et al., 2001). For this reason we suggest the inflection of uplift rate at $\sim 34 \mathrm{ka}$ is realistic.

\section{Resurgence at Toba}

Although limited, our new data provide several important constraints on the post $74 \mathrm{ka}$ history at Toba and the uplift of Samosir. The strongest constraints are for the last 33.7 ky during which the rate of uplift is revealed to have been at least $4.9 \mathrm{~cm} /$ year from 33.7 to $22.5 \mathrm{ka}$ but then decreased exponentially from $22.5 \mathrm{ka}$ to the present day (Figure 6). Numerical models of resurgence reveal that the most viable mechanism to cause this $\sim 700 \mathrm{~m}$ of cumulative uplift is clearly not regional detumescence, but instead a change in volume $(\Delta \mathrm{V})$ of the magma reservoir. A pulse-like volume change of at least $475 \mathrm{~km}^{3}$ of incompressible magma or a greater volume of compressible magma, as opposed to constant volume change, provides the best fit for the total uplift and the exponential decay of the uplift rate, although a unique combination of $\Delta \mathrm{V}$ and a viscosity model cannot be found to explain the uplift and the uplift rate roll off simultaneously. Furthermore we cannot resolve whether there were multiple pulses with the available data. More sophisticated models need to be developed to explore these possibilities. Nonetheless, the available age constraints clearly differentiate between detumescence and magmatic driving forces, and an exponentially decreasing rate in resurgent uplift is consistent with a pulse or pulses of magma and the viscoelastic response of the host rock. Furthermore, the model prediction of a minimum $\Delta V$ of $475 \mathrm{~km}^{3}$ of incompressible magma required to produce the uplift of Samosir, (if the magma is compressible, the volume would be even larger) reveals the intriguing observation that this volume of magma is similar to that of Samosir Island $\left(\sim 680 \mathrm{~km}^{3}\right)$. This suggests that the resurgent uplift of $>1 \mathrm{~km}$ is isostatically compensated by an equivalent volume of magma.

The most likely samples of this magma are the post caldera domes along the base of Samosir, i.e., the Samosir Lava Domes of the Tuk Tuk peninsula and further north (Figure 1). As reported by Chesner (2012) the composition, mineralogy, and Srisotopic ratios of these strongly resemble the YTT. Furthermore, the lava dome samples have ${ }^{40} \mathrm{Ar}-{ }^{39} \mathrm{Ar}$ ages that are all within analytical error and are indistinguishable in age from the YTT, suggesting that sanidines in the Samosir domes grew from the YTT magma. The concordance of these characteristics between the Samosir domes and the YTT suggests that the post-caldera domes are effusions of remnant YTT magma rather than new recharge magma from deeper in the crust (Chesner, 2012). We suggest that $>475 \mathrm{~km}^{3}$ remnant YTT magma rose from an unerupted volume of the magma reservoir to re-establish magmastatic equilibrium after the caldera collapse, resulting in uplift of Samosir along the Samosir fault and effusion of the Samosir lava domes. We observe a textural coarsening in the domes relative to the crystal-rich YTT suggesting that the remnant magma continued to cool and crystallize, or that, in accord with Chesner (1998) and Chesner and Luhr (2010), the untapped magma was a maturing crystal-mush. Given the model constraint of $>475 \mathrm{~km}^{3}$ of motivating magma, these facts suggest a significant volume (of supereruption proportions) of non-erupted YTT magma.

When did resurgence begin? A requirement for a pre-33.7 ka uplift and sedimentation history is given above, and given the concordance of ages of the post-caldera Samosir Lava Domes and the caldera forming eruption, the case that resurgent uplift began soon after the climactic caldera-forming eruption is reasonable. If so, the rate from 74 to $33.7 \mathrm{ka}, 1.12 \mathrm{~cm} /$ year, is considerably less than the rate immediately following it, $4.9 \mathrm{~cm} /$ year from 33.7 to $22.5 \mathrm{ka}$, and the inflection in Figure 6 suggests a change in motivating force. We speculate that from $74-33.7 \mathrm{ka}$ rebound of remnant magma was the motivation for uplift, while the rapid increase and exponential decay from $33.7 \mathrm{ka}$ implicates a deep recharge pulse (or pulses) that augmented and accelerated rebound of the remnant YTT. Deep recharge by hotter parental magmas has been suggested for the Toba system as a whole (Wark et al., 2000) and the thermal imprint of recharge is thought to be recorded in the post-caldera Samosir Lava Domes in particular (Barbee et al., 2014). These considerations suggest that the initiation of uplift at Toba has to be at least $33.7 \mathrm{ka}$ but could extend all the way back to $74 \mathrm{ka}$. Termination of uplift had to be $<8.2 \mathrm{ka}$, so a minimum duration of $25-66 \mathrm{ka}$ is implicated. 


\section{Conclusions}

${ }^{14} \mathrm{C}$ age data of post-caldera lake sediments in the Toba caldera reveal a complex post-caldera resurgence history. These data indicate that Samosir Island, the upper surface of which was the floor of the caldera that collapsed $74 \mathrm{ka}$ during the Young Toba Tuff eruption, was submerged beneath lake level (900 $\mathrm{m}$ a.s.l) $\sim 33.7 \mathrm{ky}$. Since then, post caldera resurgence of Samosir has resulted in $\sim 700 \mathrm{~m}$ of uplift in the east, while the western edge remained at or below lake level producing a tilted block dipping to the west. Using the ${ }^{14} \mathrm{C}$ age as a measure of when the uppermost sediments were last at lake level, the ages and elevations of the uppermost sediment across Samosir reveal that uplift rates were high $\sim 4.9 \mathrm{~cm} /$ year from 33.7 to $22.5 \mathrm{ka}$, but diminished to $\sim 0.7 \mathrm{~cm} /$ year from $\sim 22.5 \mathrm{ka}$ onwards.

Incorporating these rates into thermo-mechanical models to test hypotheses of the driving mechanisms of uplift of Samosir Island reveals that detumescence following caldera collapse does not produce the magnitude of uplift estimated for Samosir. However, models calculating the effect of volume changes (intrusion) into temperature-dependent viscoelastic and isoviscous host rock produce the observed resurgent uplift of Samosir as well as the exponential decay in the rates estimated from our preliminary ${ }^{14} \mathrm{C}$ dates. Initial volume predictions require a volume change of at least $475 \mathrm{~km}^{3}$ of incompressible magma to account for the uplift of Samosir, suggesting that the resurgent uplift is isostatically compensated. However, a unique combination of volume change and viscosity models cannot be found that simultaneously explain both uplift and uplift rate evolution. Resolution of this will require more sophisticated models.

A pre-33.7 ka history is required by the sedimentary and caldera history. These, in combination with ages of post-caldera Samosir Lava Domes that are indistinguishable from the age of the climactic YTT eruption, allow that resurgence may have been initiated very soon after the eruption $\sim 74 \mathrm{ka}$. The $74-33.7 \mathrm{ka}$ average uplift rate is $\sim 1.12 \mathrm{~cm} /$ year requiring a major increase in uplift rate at $\sim 33.7 \mathrm{ka}$. These constraints are consistent with a model where the initial uplift was motivated by rebound of remnant magma from 74 to $33.7 \mathrm{ka}$ and then augmented and accelerated by a deep recharge pulse at $\sim 33.7 \mathrm{ka}$. Petrological evidence for remnant YTT magma being thermally influenced by recharge in the Samosir Lava Domes reported previously supports such a model.

These new data reveal a significant post-caldera history at the Earth's youngest resurgent caldera, and constrain the duration of uplift of Samosir to a minimum duration of 25-66 ky. Uplift driven by rebound of remnant YTT magma proceeded at rates of $0.7-1.12 \mathrm{~cm} / \mathrm{s}$ for most of the uplift history. These "normal" longterm rates are much slower than those seen in active "restless" calderas, which are an order of magnitude higher. However, higher rates of $4.9 \mathrm{~cm} /$ year for a $\sim 11 \mathrm{ky}$ period at Toba may reflect the additional influence of deep recharge magma and indicates that uplift may be episodic at rates higher (and locally much higher on the $10^{0}-10^{2}$ year time scale) than normal rates of $<2 \mathrm{~cm} /$ year.
Based on Toba, and other large calderas, average rates of uplift of large resurgent domes must be much lower than active "restless" calderas to account for the protracted history of sedimentation, uplift and large footprint of the resurgent domes. This connotes different scales and character of processes for post-caldera resurgence and much later, "restlessness." The immediate post-caldera history of re-equilibration is motivated by reservoir-scale magmastatic and isostatic re-equilibration by rebound and recharge where the long term average rate of uplift $(<2-3 \mathrm{~cm} /$ year $)$ is dominated by host-rock viscosity timescales, while the amount of uplift is largely a function of volume change in the reservoir. "Restlessness" on the other hand, commonly proceeds locally at uplift rates of $10-50 \mathrm{~cm} /$ year, signaling local intrusion or hydrothermal pressurization that proceeds at much faster time scales (e.g., Kennedy et al., 2012).

\section{Acknowledgments}

Generous sabbatical support and research funds to de Silva from the Earth Observatory of Singapore (EOS) are gratefully acknowledged. This support, and the support and advice from Chris Newhall, Antonius (Purbo) Ratdomopurbo, and Kerry Sieh were invaluable in bringing this work to fruition. Craig Chesner generously shared his knowledge and advice. Mucek was supported by a US National Science Foundation Graduate Student Fellowship and a Geological Society of America Research grant. Thermomechanical modeling of caldera systems was developed while Gregg was supported by a National Science Foundation postdoctoral fellowship and the Oregon State University College of Earth, Ocean and Atmospheric Science (CEOAS) postdoctoral program. Very detailed and insightful reviews from the journal reviewers and associate editor John Stix and editorial overview by Valerio Acocella are much appreciated, These have informed our thinking, and sharpened our presentation considerably. Publication of this article in an open access journal was funded by the Oregon State University Libraries \& Press Open Access Fund.

\section{Supplementary Material}

Supplementary Table S1 for this article can be found online at: http://journal.frontiersin.org/article/10.3389/feart. 2015.00025/abstract

Table S1 | 14C sample details and analytical results.

Supplementary Figure S1 for this article can be found online at: http://www.frontiersin.org/files/pdf/Toba_Manuscript_ FigS1.pdf

Figure S1 | Toba Layered PDF. This PDF contains several different data representations as layers in a single PDF document. To navigate, open the PDF and then open the layers tool by clicking on the layer tool on the left toolbar of the PDF. Then the various layers can be toggled on and off using the layers menu. The buttons provide specific linked layer views.

The following layers are available:

Scale: The scale for the Toba Caldera is provided in the bottom left corner of the figure. This layer is locked and will remain in all views. 
Location Names: The key locations of areas mentioned in the paper, as well as the areas from which samples are collected, are pointed out in this layer, denoted by the black dot.

Sediment Locations: The locations for the different sampled sites of the sediments dated are pointed out here, denoted by the white star. Each location is also given with the sample number as seen in Table $\mathbf{S 1}$.

Caldera Outlines: The caldera outlines of the four Toba eruptions, as depicted in Chesner (2012), are reflected in this layer.

Faults and Drainages: Based on fieldwork and mapping, several different fault sequences and drainage patterns have been identified. They are shown in this layer, along with the legend that describes each feature.

$90 \mathrm{~m}$ contours: The topography of the area can be expressed in $90 \mathrm{~m}$ contours, as seen in this layer. Lake level starts at $900 \mathrm{~m}$ above sea level.

\section{References}

Acocella, V. (2007). Understanding caldera structure and development: an overview of analogue models compared to natural calderas. Earth Sci. Revi. 85, 125-160. doi: 10.1016/j.earscirev.2007.08.004

Aldiss, D. T., and Ghazali, S. A. (1984). The regional geology and evolution of the Toba volcano-tectonic depression, Indonesia. J. Geol. Soc. 141, 487-500. doi: 10.1144/gsjgs.141.3.0487

Barbee, O., Chesner, C. A., and Reid, M. (2014). "Quartz recrystallization in the Youngest Toba Tuff magma chamber and its remnants: a complex lineage uncovered by CL zoning," in Fall Meeting of the American Geophysical Union Abstract V51C-4764 (San Francisco, CA).

Chen, J. K., Taylor, F. W., Edwards, R. L., Cheng, H., and Burr, G. S. (1995). Recent emerged reef terraces of the Yenkahe resurgent block, Tanna, Vanuatu: implications for volcanic, landslide and tsunami hazards. J. Geol. 103, 577-590. doi: 10.1086/629777

Chery, J., Bonneville, A., Vilotte, J. P., and Yuen, D. (1991). Numerical modelling of caldera dynamical behaviour. Geophys. J. Int. 105, 365-379. doi: 10.1111/j.1365246X.1991.tb06719.x

Chesner, C. A. (1998). Petrogenesis of the Toba Tuffs, Sumatra, Indonesia. J. Petrol. 39, 397-438. doi: 10.1093/petroj/39.3.397

Chesner, C. A. (2012). The Toba caldera complex. Q. Int. 258, 5-18. doi: 10.1016/j.quaint.2011.09.025

Chesner, C. A., and Luhr, J. F. (2010). A melt inclusion study of the Toba Tuffs, Sumatra, Indonesia. J. Volcanol. Geotherm. Res. 197, 259-278. doi: 10.1016/j.jvolgeores.2010.06.001

Chesner, C. A., and Rose, W. I. (1991). Stratigraphy of the Toba tuffs and the evolution of the Toba caldera complex, Sumatra, Indonesia. Bull. Volcanol. 53, 343-356. doi: 10.1007/BF00280226

Chesner, C., Rose, W. I., Deino, A. L., Drake, R., and Westgate, J. A. (1991). Eruptive history of Earth's largest Quaternary caldera (Toba, Indonesia) clarified. Geology 19, 200-203. doi: 10.1130/0091-7613(1991) $019<0200$ :EHOESL> 2.3.CO;;2

Colman, S. M., Karabanov, E. B., and Nelson, C. H. (2003). Quaternary sedimentation and subsidence history of Lake Baikal, Siberia, based on seismic stratigraphy and coring. J. Sediment. Res. 73, 941-956. doi: $10.1306 / 041703730941$

Del Negro, C., Currenti, G., and Scandura, D. (2009). Temperature-dependent viscoelas- tic modeling of ground deformation: application to Etna volcano during the 1993-1997 inflation period. Phys. Earth Planet. Inter. 172, 299-309. doi: 10.1016/j.pepi.2008.10.019

de Silva, S. L., and Gosnold, W. D. (2007). Episodic construction of batholiths: insights from the spatiotemporal development of an ignimbrite flare-up. J. Volcanol. Geotherm. Res. 167, 320-335. doi: 10.1016/j.jvolgeores.2007. 07.015

de Silva, S. L., and Gregg, P. M. (2014). Journal of volcanology and geothermal research. J. Volcanol. Geotherm. Res. 282, 77-91. doi: 10.1016/j.jvolgeores.2014.06.001
Toba Deposits: The two main types of deposits identified in the Toba Caldera are lava domes and lake sediments. The distribution of these deposits around the caldera is shown in this layer, based on fieldwork and previous literature. The base map of this layer is a sketch of the Toba Caldera.

DEM (30 m SRTM): A colored Digital Elevation Model from a $30 \mathrm{~m}$ SRTM is provided as a layer.

Apple Map: Satellite imagery of Toba as shown in Apple Maps is provided as a layer.

GoogleEarthLayer: Satellite image of Toba as shown in Google Earth (2012) is provided as a layer.

Toba Outline: A sketch the Toba Caldera is provided. Outline of the caldera is based on Google Earth satellite imagery (2012). This layer is locked and will remain in all views. An Adobe Illustrator file is available by request from the authors.

Dzurisin, D., Wicks, C. Jr, and Thatcher, W. (1999). Renewed uplift at the Yellowstone Caldera measured by leveling surveys and satellite radar interferometry. Bull. Volcanol. 61, 349-355. doi: 10.1007/s004450050277

Edgington, D. N., Klump, J. V., Robbins, J. A., Kusner, Y. S., Pampura, V. D., and Sandimirov, I. V. (1991). Sedimentation rates, residence times and radionuclide inventories in Lake Baikal from $137 \mathrm{Cs}$ and $210 \mathrm{~Pb}$ in sediment cores. Nature 350, 601-604. doi: 10.1038/350601a0

Feigl, K. L., Le Mevel, H., Tabrez Ali, S., Cordova, L., Andersen, N. L., DeMets, C., et al. (2014). Rapid uplift in Laguna del Maule volcanic field of the Andean Southern Volcanic zone (Chile) 2007-2012. Geophys. J. Int. 196, 885-901. doi: $10.1093 /$ gji/ggt438

Fernex, F., Zárate-del Valle, P., Ramìrez-Sánchez, H., Michaud, F., Parron, C., and Dalmasso, J. (2001). Sedimentation rates in Lake Chapala (western Mexico): possible active tectonic control. Chem. Geol. 177, 213-228. doi: 10.1016/S00092541(00)00346-6

Fisher, R. V., Heiken, G., and Hulen, J. B. (1997). Volcanoes: Crucibles of Change. Princeton, NJ: Princeton University Press.

Folkes, C. B., Wright, H. M., Cas, R. A. F., de Silva, S. L., Lesti, C., and Viramonte, J. G. (2011). A re-appraisal of the stratigraphy and volcanology of the Cerro Galan volcanic system, NW Argentina. Bull. Volcanol. 73, 1427-1454. doi: 10.1007/s00445-011-0459-y

Goff, F., Gardner, J. N., Hulen, J. B., Nielson, D. L., Charles, R., WoldeGabriel, G., et al. (1992). The Valles caldera hydrothermal system, past and present, New Mexico, USA. Sci. Drill 3, 181-204.

Gregg, P. M., de Silva, S. L., and Grosfils, E. B. (2013). Thermomechanics of shallow magma chamber pressurization: implications for the assessment of ground deformation data at active volcanoes. Earth Planet. Sci. Lett. 384, 100-108, doi: 10.1016/j.epsl.2013.09.040

Gregg, P. M., de Silva, S. L., Grosfils, E. B., and Parmigiani, J. P. (2012). Catastrophic caldera-forming eruptions: thermomechanics and implications for eruption triggering and maximum caldera dimensions on Earth. J. Volcanol. Geotherm. Res. 241, 1-12. doi: 10.1016/j.jvolgeores.2012. 06.009

Haslam, M., and Petraglia, M. (2010). Comment on "Environmental impact of the $73 \mathrm{ka}$ Toba super-eruption in South Asia" by MAJ Williams, SH Ambrose, S. van der Kaars, C. Ruehlemann, U. Chattopadhyaya, J. Pal and PR Chauhan [Palaeogeography, Palaeoclimatology, Palaeoecology 284 (2009) 295-314]. Palaeogeogr. Palaeoclimatol. Palaeoecol. 296, 199-203. doi: 10.1016/j.palaeo.2009.10.009

Jackson, S. M., Smith, R. B., and Olsen, T. L. (1984). Recent uplift of the Yellowstone caldera from precision gravity measurements. Eos. Trans. Am. Geophy. Union 65, 1118

Jones, S. C. (2012). Local-jand regional-jscale impacts of the $74 \mathrm{ka}$ Toba supervolcanic eruption on hominin populations and habitats in India. Q. Int. 258, 100-118. doi: 10.1016/j.quaint.2011.09.017

Kaizuka, S., Newhall, C., Oyagi, N., and Yagi, H. (1989). Remarkable unrest at Iwojima caldera. Volcanic Islands, Japan. New Mex. Bur. Mine Miner. Resour. Bull. $13,146$. 
Kennedy, B., Wilcock, J., and Stix, J. (2012). Caldera resurgence during magma replenishment and rejuvenation at Valles and Lake City calderas. Bull. Volcanol. 74, 1833-1847. doi: 10.1007/s00445-012-0641-x

Knight, M. D., Walker, G. P., Ellwood, B. B., and Diehl, J. F. (1986). Stratigraphy, paleomagnetism, and magnetic fabric of the Toba Tuffs: constraints on the sources and eruptive styles. J. Geophys. Res. 91, 10355-10382. doi: 10.1029/JB091iB10p10355

Lindsay, J. M., Schmitt, A. K., Trumbull, R. B., de Silva, S. L., Siebel, W., and Emmermann, R. (2001). Magmatic evolution of the La Pacana caldera system, Central Andes, Chile: compositional variation of two cogenetic, large-volume felsic ignimbrites. J. Petrol. 42, 459-486. doi: 10.1093/petrology/42.3.459

Lipman, P. W. (1975). Evolution of the Platoro Caldera Complex and Related Volcanic Rocks, Southeastern San Juan Mountains, Colorado: A Study of Relations between Ash-flow Eruptions, Lava-flow Activity and Caldera Structure at a Mineralized Volcanic Center. Washington, DC: US Government Printing Office.

Lipman, P. W. (1984). The roots of ash flow calderas in western North America: windows into the tops of granitic batholiths. J. Geophys. Res. 89, 8801-8841. doi: 10.1029/JB089iB10p08801

Mark, D. F., Petraglia, M., Smith, V. C., Morgan, L. E., Barfod, D. N., Ellis, B. S., et al. (2013). A high-precision ${ }^{40} \mathrm{Ar} /{ }^{39} \mathrm{Ar}$ age for the Young Toba Tuff and dating of ultra-distal tephra: forcing of Quaternary climate and implications for hominin occupation of India. Quaternary Geochronol. doi: 10.1016/j.quageo.2012.12.004

Marsh, B. D. (1984). On the mechanics of caldera resurgence. J. Geophys. Res. 89, 8245-8251. doi: 10.1029/JB089iB10p08245

Mastin, L. G., Van Eaton, A. R., and Lowenstern, J. B. (2014). Modeling ash fall distribution from a Yellowstone supereruption, Geochem. Geophys. Geosyst. 15, 3459-3475, doi: 10.1002/2014GC005469

Miller, C. F., and Wark, D. A. (2008). Supervolcanoes and their explosive supereruptions. Elements 4, 11-15. doi: 10.2113/GSELEMENTS.4.1.11

Newhall, C. G., and Dzurisin, D. (1988). Historical unrest at large calderas of the world. U.S. Geol. Surv. Bull. 1855, 1-1108.

Oppenheimer, C. (2002). Limited global change due to the largest known Quaternary eruption, Toba $\sim 74 \mathrm{kyr}$ BP. Quaternary Sci. Rev. 21, 1593-1609. doi: 10.1016/S0277-3791(01)00154-8

Oppenheimer, S. (2012). A single southern exit of modern humans from Africa: before or after Toba. Quaternary Int. 258, 88-99. doi: 10.1016/j.quaint.2011.07.049

Orsi, G., Civetta, L., Del Gaudio, C., De Vita, S., Di Vito, M. A., Isaia, R., et al. (1999). Short-term ground deformations and seismicity in the resurgent Campi Flegrei caldera (Italy): an example of active block-jresurgence in a densely populated area. J. Volcanol. Geotherm. Res. 91, 415-451. doi: 10.1016/S03770273(99)00050-5

Orsi, G., Gallo, G., and Zanchi, A. (1991). Simple-shearing block resurgence in caldera depressions. A model from Pantelleria and Ischia. J. Volcanol. Geotherm. Res. 47, 1-11. doi: 10.1016/0377-0273(91)90097-J

Pelton, J. R., and Smith, R. B. (1979). Recent crustal uplift in Yellowstone National Park. Science 206, 1179-1182. doi: 10.1126/science.206.4423.1179

Phillips, E. H., Goff, F., Kyle, P. R., McIntosh, W. C., Dunbar, N. W., and Gardner, J. N. (2007). The ${ }^{40} \mathrm{Ar} /{ }^{39} \mathrm{Ar}$ age constraints on the duration of resurgence at the Valles caldera, New Mexico. J. Geophys. Res. 112:B08201. doi: 10.1029/2006JB004511

Ramsey, C. B. (2009). Bayesian analysis of radiocarbon dates. Radiocarbon 51, 337-360. doi: 10.2458/azu_js_rc.v.3494

Reimers, P. J., Baillie, M. G. L., Bard, E., Bayliss, A., Beck, J. W., and Weyhenmeyer, C. E. (2009). Intcal09 and Marine09 radiocarbon age calibration curves, 050,000 years cal BP. Radiocarbon 51, 1111-1150. Available online at: http://hdl. handle.net/1893/19151

Roche, O., and Druitt, T. H. (2001). Onset of caldera collapse during ignimbrite eruptions. Earth Planet. Sci. Lett. 191, 191-202. doi: 10.1016/S0012$821 \mathrm{X}(01) 00428-9$
Sacchi, M., Pepe, F., Corradino, M., Insinga, D. D., Molisso, F., and Lubritto, C. (2014). The Neapolitan Yellow Tuff caldera offshore the Campi Flegrei: stratal architecture and kinematic reconstruction during the last 15ky. Marine Geol. 354, 15-33. doi: 10.1016/j.margeo.2014.04.012

Santos, G. M., Moore, R. B., Southon, J. R., Griffin, S., Hinger, E., and Zhang, D. (2007). AMS ${ }^{14} \mathrm{C}$ sample preparation at the KCCAMS/UCI Facility: status report and performance of small samples. Radiocarbon 49, 255-269. doi: $10.2458 /$ azu_js_rc.v.2925

Saunders, S. (2001). The shallow plumbing system of Rabaul caldera: a partially intruded ring fault? Bull. Volcanol. 63, 406-420. doi: 10.1007/s0044501 00159

Saunders, S. J. (2004). The possible contribution of circumferential fault intrusion to caldera resurgence. Bull. Volcanol. 67, 57-71. doi: 10.1007/s00445-004-0360-z

Savage, J. C., and Clark, M. M. (1982). Magmatic resurgence in Long Valley caldera, California: possible cause of the 1980 Mammoth Lakes earthquakes. Science 217, 531-533. doi: 10.1126/science.217.4559.531

Self, S., and Blake, S. (2008). Consequences of explosive supereruptions. Elements 4, 41-46. doi: 10.2113/GSELEMENTS.4.1.41

Smith, R. B., and Braile, L. W. (1994). The Yellowstone hotspot. J. Volcanol. Geotherm. Res. 61, 121-187. doi: 10.1016/0377-0273(94)90002-7

Smith, R. L., and Bailey, R. A. (1968). Resurgent cauldrons. Mem. Geol. Soc. Am. 116, 613-662. doi: 10.1130/mem116-p613

Sorey, M. L., McConnell, V. S., and Roeloffs, E. (2003). Summary of recent research in Long Valley caldera, California. J. Volcanol. Geotherm. Res. 127, 165-173. doi: 10.1016/S0377-0273(03)00168-9

Storey, M., Roberts, R. G., and Saidin, M. (2012). Astronomically calibrated ${ }^{40} \mathrm{Ar} /{ }^{39} \mathrm{Ar}$ age for the Toba supereruption and global synchronization of late Quaternary records. Proc. Natl. Acad. Sci. U.S.A. 109, 18684-18688. doi: 10.1073/pnas. 1208178109

Tibaldi, A., and Vezzoli, L. (2004). A new type of volcano flank failure: the resurgent caldera sector collapse, Ischia, Italy. Geophys. Res. Lett. 31, L14605. doi: 10.1029/2004GL020419

van Bemmelen, R. W. (1929). "The origin of Lake Toba (North Sumatra)," in Proceedings of the 4th Pacific Science Congress (Batavia, IL).

van Bemmelen, R. W. (1939). "The volcano-tectonic origin of Lake Toba (North Sumatra)," in De Ingenieur in Nederlandsch, Vol. 6-9, 126-140.

Verstappen, H. T. (1973). A Geomorphological Reconnaissance of Sumatra and Adjacent Islands (Indonesia). Groningen: Wolters-Noordhoff.

Wark, D. A., Masturyono, M., McCaffrey, R., Farmer, G. L., Rani, and, M., and Sukhyar, R. (2000). Plumbing of the Toba magma system; petrologic and geophysical evidence of two shallow reservoirs and their mantle roots. Eos Transact. Am. Geophys. Union 81e48, 1387.

Williams, M. (2012). Did the 73 ka Toba super-`eruption have an enduring effect? Insights from genetics, prehistoric archaeology, pollen analysis, stable isotope geochemistry, geomorphology, ice cores, and climate models. Quaternary Int. 269, 87-93. doi: 10.1016/j.quaint.2011.03.045

Williams, M. A., Ambrose, S. H., van der Kaars, S., Ruehlemann, C., Chattopadhyaya, U., Pal, J., et al. (2009). Environmental impact of the 73ka Toba super-eruption in South Asia. Palaeogeogr. Palaeoclimatol. Palaeoecol. 284, 295-314. doi: 10.1016/j.palaeo.2009.10.009

Conflict of Interest Statement: The authors declare that the research was conducted in the absence of any commercial or financial relationships that could be construed as a potential conflict of interest.

Copyright $\odot 2015$ de Silva, Mucek, Gregg and Pratomo. This is an open-access article distributed under the terms of the Creative Commons Attribution License (CC BY). The use, distribution or reproduction in other forums is permitted, provided the original author(s) or licensor are credited and that the original publication in this journal is cited, in accordance with accepted academic practice. No use, distribution or reproduction is permitted which does not comply with these terms. 